This item was submitted to Loughborough's Research Repository by the author.

Items in Figshare are protected by copyright, with all rights reserved, unless otherwise indicated.

\title{
Prediction of size distribution of crude oil drops in the permeate using a slotted pore membrane
}

PLEASE CITE THE PUBLISHED VERSION

http://dx.doi.org/10.1016/j.cherd.2014.02.017

\section{PUBLISHER}

(c) The Institution of Chemical Engineer . Published by Elsevier

\section{VERSION}

AM (Accepted Manuscript)

\section{PUBLISHER STATEMENT}

This work is made available according to the conditions of the Creative Commons Attribution-NonCommercialNoDerivatives 4.0 International (CC BY-NC-ND 4.0) licence. Full details of this licence are available at: https://creativecommons.org/licenses/by-nc-nd/4.0/

\section{LICENCE}

CC BY-NC-ND 4.0

\section{REPOSITORY RECORD}

Ullah, Asmat, R.G. Holdich, M. Naeem, S.W. Khan, and Victor Starov. 2017. "Prediction of Size Distribution of Crude Oil Drops in the Permeate Using a Slotted Pore Membrane". figshare.

https://hdl.handle.net/2134/25767. 


\section{Elsevier Editorial System(tm) for Chemical Engineering Research and Design Manuscript Draft}

Manuscript Number: CHERD-D-13-00221

Title: Prediction of size distribution of crude oil drops in the permeate using a slotted pore membrane

Article Type: Full Length Article

Keywords: Permeate size distribution prediction, Slotted pore membranes, Deforming drops, Microfiltration

Corresponding Author: Mr. Asmat Ullah, PhD

Corresponding Author's Institution: Loughborough University

First Author: Asmat Ullah, PhD

Order of Authors: Asmat Ullah, PhD

Abstract: Permeate size distribution of various crude oil drops with, and without, oscillating the membrane has been predicted using the 'Linear Fit' approach. Drops pass through the membrane due to drag force created by the flow of fluid around the drops. Static force is the force responsible for the rejection of drops through the membrane and is directly proportional to the interfacial tension between dispersed and continuous phases. Without applied shear, 100\% cut-off of drops though the membrane is assumed when the drag force and the static force balances each other. With the applied shear, $100 \%$ cut-off of drops through the membrane is when drops moves away from the membrane surface due to migration velocities and do not pass the membrane into the permeate. Extrapolating $100 \%$ cut-off to the origin of the rejection graphs gives a straight line that is referred as 'Linear Fit' and can be used for predicting rejection below $100 \%$ cut-off. Linear fit can be used for predicting drop rejection below $100 \%$ cut-off. The portion of oil that would not be rejected by the membrane and would pass through the membrane into the permeate can be calculated using this approach. For a given size of drops in a feed suspension, permeate size distribution can be predicted by multiplying the fraction of oil passing through the membrane and the feed size distribution data. Overall concentration of oil in the permeate can be calculated by knowing size distribution of drops in the permeate, and that provides an idea whether the concentration of oil in the permeate is below the standard set by international regulatory authorities.

Suggested Reviewers: Sergy Semenov

Loughborough University

s.semionov_1266@mail.ru

Expert in the area

Anatoly Filippov

Gubkin Russian State University of Oil and Gas

a.filippov@mtu-net.ru

Expert in the area

Arthanareeswaran Gangasalam

National Institute of Technology, India 
arthanaree10@yahoo.com

Expert in the area

Nidal Hilal

University of Wales Swansea

N.Hilal@swansea.ac.uk

Leading expert in the area 
Chemical Engineering Research and Design

Editorial Office

Direct Line:+44 (0)1509 222508

Fax: +44 (0)1509 223923

E-mail: V.M.Starov@Lboro.ac.uk

http://www.lboro.ac.uk/departmets/cg/staff/cgvms.htm

13 March, 2013

Dear Dr Eva Sørensen,

WE SUBMIT OUR MANUSCRIPT

"Prediction of size distribution of crude oil drops in the permeate using a slotted pore membrane" by A. Ullah, R.G. Holdich, M. Naeem, S.W. Khan. V.M. Starov for a publication in Chemical Engineering Research and Design.

Yours sincerely

Victor

Department of Chemical Engineering

Loughborough University

Ashby Rd, Loughborough,

Leicestershire, LE 11 3TU, UK

Tel +44-(0)1509 222508

Fax +44-(0)1509 223923

e-mail V.M.Starov@lboro.ac.uk

http://www.lboro.ac.uk/departments/cg/staff/starov.html

Professor BW Brooks DSc CEng FIChemE :

Professor BA Buffham DSc(Eng) CEng FIChemE

Professor CD Rielly PhD CEng MIChemE :

Professor VM Starov DSc PhD MSc

Professor M Streat PhD DIC CEng FREng FIChemE :

Professor RJ Wakeman EurIng PhD CEng FREng FIChemE 
- Crude oil drops are passed through a slotted pore membrane, with, and without oscillating the membrane.

- Higher mass of crude oil in the permeate is obtained at higher flux rates.

- Permeate size distribution of crude oil drops is predicted based on 'linear fit' approach. 
Prediction of size distribution of crude oil drops in the permeate using a slotted pore membrane.

\section{A. Ullah ${ }^{*}$,a,b, R.G. Holdicha, M. Naeemc, S.W. Khand, V.M. Starova}

*To whom correspondence should be addressed: A.Ullah@lboro.ac.uk, asmatuet@gmail.com

aDepartment of Chemical Engineering Loughborough University, Leicestershire LE11 3TU, UK.

bDepartment of Chemical Engineering KPK UET Peshawar Pakistan.

'Department of Chemistry AWKUM Mardan Pakistan.

dSchool of Civil and Building Engineering Loughborough University, Leicestershire LE11 3TU, UK.

\section{ABSTRACT}

Permeate size distribution of various crude oil drops with, and without, oscillating the membrane has been predicted using the 'Linear Fit' approach. Drops pass through the membrane due to drag force created by the flow of fluid around the drops. Static force is the force responsible for the rejection of drops through the membrane and is directly proportional to the interfacial tension between dispersed and continuous phases. Without applied shear, $100 \%$ cut-off of drops though the membrane is assumed when the drag force and the static force balances each other. With the applied shear, $100 \%$ cut-off of drops through the membrane is when drops moves away from the membrane surface due to migration velocities and do not pass the membrane into the permeate. 
Extrapolating $100 \%$ cut-off to the origin of the rejection graphs gives a straight line that is referred as 'Linear Fit' and can be used for predicting rejection below 100\% cut-off. Linear fit can be used for predicting drop rejection below 100\% cut-off. The portion of oil that would not be rejected by the membrane and would pass through the membrane into the permeate can be calculated using this approach. For a given size of drops in a feed suspension, permeate size distribution can be predicted by multiplying the fraction of oil passing through the membrane and the feed size distribution data. Overall concentration of oil in the permeate can be calculated by knowing size distribution of drops in the permeate, and that provides an idea whether the concentration of oil in the permeate is below the standard set by international regulatory authorities.

KEYWORDS: Permeate size distribution prediction, Slotted pore membranes, Deforming drops, Microfiltration.

\section{INTRODUCTION}

Oil in water is associated with many environmental problems and needs to be separated efficiently. It is a threat for life in water and the concentration of oil in the sea water is limited to $30 \mathrm{mg} \mathrm{l}^{-1}$ or below [1]. Initially, hydrocyclones were used as primary separators, but the separations targets for drops below $40 \mu \mathrm{m}$ were not achieved and the process was expensive [2-4].

In recent years, membrane separation technology has attracted researchers for oil/water separation [5]. Ultrafiltration is useful with low oil content, but a lower permeate flux rate was achieved, normally lower than $100 \mathrm{l} \mathrm{m}^{-2} \mathrm{hr}^{-1}$; which is too low to be commercially attractive for offshore operations [6, 7]. Microfiltration is an efficient 
process for oil/water separation with drops below $10 \mu \mathrm{m}$ and due to several advantages like: low space requirement, high permeate flux and high permeate quality; microfiltration is distinct from conventional separation methods [8-12]. Surface microfiltration is found effective than depth microfiltration because the membrane used in surface microfiltration can be cleaned easily after the process [13]. Pore structure design has attracted researchers and circular pore membranes with surface filtration filters are found efficient in oil/water separation [13]. Slotted pore membranes were found less foulent and higher permeate flux and better separation of filtering material were achieved specially with deforming oil drops as compared to circular pore membranes [14-19].

Shear rate over the membrane surface is provided at higher fluid velocity in crossflow microfiltration that reduced fouling of the membrane [11]. Crossflow microfiltration is very expensive and more energy is required for pumping the fluid again and again into the system [20,21]. Shear enhanced dynamic microfiltration is an alternative to crossflow microfiltration, in which shear is produced due to vibrating/rotating the membrane and the process is more economical [21]. Four times lower trans-membrane pressure is observed by vibrating the membrane with $21 \mathrm{~Hz}$ during filtration of deforming oil drops $[17,18]$. Similarly, vibrating the membrane increased separation efficiency of crude oil drops from water and separation increased linearly with increasing vibrating frequency of the used membrane [19].

Overall oil concentration in the permeate is an important factor and it has to be below the standard set by international regulation authorities for oil content in water if the permeate is discharge into sea waters. Predicting size distraction in the permeate provide an opportunity to calculate overall oil concentration in the permeate at various 
flux rates and different interfacial tension systems with, without oscillating the membrane. The study provides a model for predicting size distribution in the permeate for a $4 \mu \mathrm{m}$ slotted pore membrane and the presented model in the paper can be applied for different membrane with slots widths when different filtering materials.

\section{THEORY}

Static force $\left(F_{c x}\right)$ is the force responsible for the rejection of drops through the membrane without shear applied to the surface of the membrane and can be expressed as follows: [15],

$\left.F_{c x}=-\left(2 \pi R_{s p} \sigma\left(\left(\frac{2 h}{R_{s p}}\right)+\left(\frac{-3\left(\frac{h}{R s_{p}}\right)^{3}-\arccos \left(\frac{h}{R_{s p}}\right)^{3} \frac{1}{2 \sqrt{1-\left(\frac{h}{R_{s p}}\right)^{6}}}\left(-8\left(\frac{h}{R_{s p}}\right)^{6}+2\right)}{\left(\frac{h}{R_{s p}} \sqrt{1-\left(\frac{h}{R_{s p}}\right)^{6}}\right)^{2}}\right)\right)\right)\right) \sin \frac{\alpha}{2}$

Where $\sigma$ is interfacial tension between oil/water, $R_{s p}$ is the radius of the drop, and $h$ is the half width of slot of the membrane.

The drag force exerted on a sphere moving between two plates is given in $[1,22]$ as:

$F_{d}=k_{w} 12 \pi \eta R_{s p} U$.

Where $k_{w}$ is a wall correction factor and for a similar system its value is equal to 4.3 [1]. $\eta$ is viscosity of the fluid, $R_{s p}$ is the radius of the spherical droplet and $U$ is the velocity of the fluid through the slot. The drop is under steady state conditions inside the pore, 
when $F_{c x}$ becomes equal to $F_{d}$ and the drops will be captured in this position. The drop will deform and will pass through the membrane when $F_{d}>F_{c x}$ and it will be rejected by the membrane in the case of $F_{d}<F_{c x}[15]$.

When shear is applied (whether the applied shear is due to crossflow velocity or oscillating the membrane) to the membrane surface there is a lift present in the system, and due to the lift, drops moves away from the membrane surface [23]. Lift due to crossflow velocity through the membrane is referred as 'Inertial lift' and the model used for 'Inertial lift' is used as a starting point knowing that the system used in the study is oscillating flow system and a higher lift is present. Inertial lift migration created due to applied shear rate that opposed permeate velocity [24]. Migration velocity under fast laminar flow (the model is used as a starting point) conditions of a drop due to inertial lift, $v_{i f}$, was deduced in [24]:

$v_{i f}=\frac{0.036 \rho_{f} \dot{\gamma}^{2} R_{s p}^{3}}{\eta}$.

Where $\rho_{f}$ is density of the fluid, $\eta$ is viscosity of the fluid, $\dot{\gamma}$ is the applied shear rate and $R_{s p}$ radius of the drop.

Dilute oil/water emulsion is used, so, particle to particle interaction is assumed to be negligible in our case. Inertial lift velocity can be calculated using equation (3). Migration velocity due to inertial lift is directed oppositely to the convection, $v_{0}^{\prime}$, caused by the flowing liquid. This consideration shows that drops reach the surface of the membrane with a velocity, $v^{\prime}$, which is lower than the velocity of the flowing liquid: 
$v^{\prime}=v_{0}^{\prime}-v_{i f}=v_{0}^{\prime}-\frac{0.036 \rho_{f} \dot{\gamma}^{2} R_{s p}^{3}}{\eta}$.

This expression is used for comparison with the experimental data.

For a given shear rate and convection velocity or superficial velocity $\left(v_{0}^{\prime}\right)$, critical drop size would be the one at which $v^{\prime}$ become negative. Critical radius can be obtained using equation (4). For a given convection velocity, critical radius of drops would different at different shear rates. If velocity of the drops on the membrane surface becomes negative then the drops cannot pass the membrane into the permeate and will be transferred away from the membrane.

For a given drop size and convection velocity, critical shear rate $\left(\dot{\gamma}_{c r}\right)$ is the one at which migration velocities of drops due to inertial lift become greater than convection velocity of the drops. For a given drop size and convection velocity, critical shear rate can be obtain using equation (4). For a given convection velocity, drops with different sizes having different critical shear rates. Similarly, for a given drop size, at different convection velocities critical shear rate would be different.

In case of without applied shear, $100 \%$ cut-off of oil drops through the membrane is assumed when equation (1) and (2) balances each other. Extrapolating 100\% cut-off to the origin of rejection graphs gives a straight line that is referred as 'Linear fit' and can be used for predicting rejection of drops below 100\% cut-off [15]. 'Linear fit' provide the idea of fraction of oil rejected and passed through the membrane. In the case of applied shear to the membrane surface $100 \%$ cut-off of oil drop through the membrane is assumed when $v^{\prime}$ becomes negative in equation (4). 


\section{MATERIALS AND METHOD}

Crude oil was provided by North Sea oil companies. A $4 \mu \mathrm{m}$ slotted pore membrane was used for separating oil drops from produced water; see Figure 1 of [18]. Experimental tests were carried out with a vibrating microfiltration rig provided by micro-pore technologies UK for schematic view of the rig see Figure 3 of [18]. Experimental set-up for filtration without membrane oscillating is provided in Figure 3 of [15]. Full details about the used materials and experimental procedure are provided in $[15,18]$.

\section{RESULTS AND DISCUSSION}

Drops of crude oil $\left(22,27\right.$ and $\left.30{ }^{\circ} \mathrm{API}\right)$ from crude oil provided by North Sea oil operating companies were made in produced water, with a food blender, operated for 12 mins at its highest speed, and feed size distributions can be seen in Figure 1. Once the drops are produced, then the feed size can be nearly maintained constant by gently stirring the emulsion. The difference in feed size distribution of different crude oil drops may be due to different viscosities, interfacial tensions and densities. It has been noticed that the higher the API value of a crude oil, the lower interfacial tension between dispersed and continuous phases observed [15]. Static force $\left(F_{c x}\right)$ and can be calculated using equation (1) is a linear function of interfacial tension $(\sigma)$ between dispersed and continuous phases $[1,15]$. It means that the higher the interfacial tension $(\sigma)$ between dispersed and continuous phases; the higher would be rejection of crude oil drops through the membrane; and a lower portion of drops would be passing through the membrane into the permeate [15]. Similarly, $100 \%$ cut-off is the point when equation (1) and (2) balances each other is an inverse function of interfacial tension $(\sigma)$ between dispersed and continuous phases. Applied shear rate to the membrane surface also influences the $100 \%$ cut-off of drops through the membrane [17]. Shear rates produce 
migration velocities of drops away from the surface of the membrane and due to it some drops do not reach the surface of the membrane [17]. Migration velocities away from membrane surface are a linear function of the applied shear rate [17, 24]. So, applied shear rate decreases the $100 \%$ cut-off value of drops through the membrane.

Drops pass through the membrane into the permeate due to drag force $\left(F_{d}\right)$ offered by the flow of fluid around the drops and can be calculated using equation (2) [1, 15]. Drag force $\left(F_{d}\right)$ is a linear function of permeate flux rate $\left(v_{0}^{\prime}\right)$ : higher the flux rate $\left(v_{0}^{\prime}\right)$, higher would be the drag force $\left(F_{d}\right)$ around the drops $[1,15]$. This shows that at higher flux rate a larger number of drops would pass through the membrane as compared to low flux rates. Similarly, like drag force, $100 \%$ cut-off point (when equation (1) = equation (2) without applied shear rate; and when equation (4) becomes negative in the case of applied shear rate) is a linear function of flux rate. Extrapolating $100 \%$ cut-off point to the origin of the graph produced a straight line and was referred as linear fit [15]. Linear fit can be used for predicting rejection of drops below the $100 \%$ cut-off. The idea of linear fit can be further extended for predicting size distributions of drops in the permeate. For a given size of drop, predicted permeate size distribution can be obtained by multiplying the fraction of drops passed through the membrane to the feed size distribution. Permeate size distribution mainly depends on feed size distribution, interfacial tension $(\sigma)$ between dispersed and continuous phases, flux rate $\left(v_{0}^{\prime}\right)$ and size of slot/pore of the used membrane.

Figures 2 (a)-(c) show predicted and experimental permeate size distributions of crude oils 22, 27, $30{ }^{\circ} \mathrm{API}$ respectively. Predicted lines in Figures 2 (a)-(c) means data obtain from the 'linear fit' approach. The crude oils were provided by North Sea oil operating 
companies. From the linear fit, at different points, the fraction of oil drops through the membrane is obtained. The fraction of oil drops passed through the membrane decreased moving from down to up on the linear fit line and reached zero at the $100 \%$ cut-off point. At the same flux rate, the fraction of oil drops passed through the membrane is higher for crude oil having high API values as compared to lower API crude oil due to the fact that higher API crude oil offers lower interfacial tension $(\sigma)$. Lower interfacial tension means a lower static force $\left(F_{c x}\right)$, which is responsible for the rejection of drops through the membrane $[1,15]$. It is also clear from Figures 2 (a), (b) and (c) that an increase in the flux rate increases the passage of drops through the membrane for all crude oil drops tested during experiments. It has been noticed that a large portion of oil by mass passed through the membrane below the size of the slot due to the fact that resistance to the drag force $\left(F_{d}\right)$ below the size of slot/pore was a minimum. Due to a higher resistance offered by the static force to the drops above slot size, a lower portion of drops above slot size passed through the membrane. Coulter analysed $2 \mathrm{ml}$ sample, and the mass recovered both in the feed and in the permeate by the Coulter was actually mass of oil in $2 \mathrm{ml}$ sample. Based on $2 \mathrm{ml}$ sample calculations, mass of oil in the feed and in the permeate in ppm can easily be obtained.

Oscillating the membrane with various frequencies created shear rates $(\dot{\gamma})$ of different intensities over the surface of the membrane $[18,25]$. Migration velocities (Inertial lift migration velocities) away from the surface of the membrane are created due to the applied shear rate to the membrane $[17,24]$. Migration velocities $\left(v_{i f}\right)$ are a linear function to the applied shear rate $[17,24]$. Its means lower mass of crude would pass through the membrane with the higher shear rate. Figure 3 (a) and (b) show experimental and predicted size distributions by mass of crude oil ( $\left.31^{\circ} \mathrm{API}\right)$ at different 
shear rates and flux rates. The theory is in satisfactory agreement with the experiments that shows that the linear fit idea can be successfully applied to predict permeate size distribution of deforming drops with, and without, shear.

Table 1 shows a measured size distribution of published data for crude oil ( $32{ }^{\circ} \mathrm{API}, 29$ ${ }^{\circ} \mathrm{API}$ ) samples in various continuous phases of a Kuwait oil company [26]. This data is used in order to demonstrate the linear fit approach for predicting size distribution in the permeate for various crude oil drops obtained at different locations. It can be seen in Table 1 that a large number of drops are above $4 \mu \mathrm{m}$. Based on their API values, interfacial tensions between dispersed and continuous phases can be assumed. 100\% cut-off points through a $4 \mu \mathrm{m}$ slotted pore membrane can be assumed on the basis of API values. On the basis of $100 \%$ cut-off and linear fit approach, permeate size distributions at different flux rates for crude oil obtained from this Kuwait oil company can be predicted. Feed size distribution of crude oil drops in different continuous phases is provided in Figure 4 (a) and (b). Predicted permeate size distributions based on a linear fit for crude oil $\left(29,32^{\circ} \mathrm{API}\right)$ at different rates are illustrated in Figures 5 (a), (b) (c) and (d).

Size distributions of crude oil drops in the permeate can be predicted knowing size distribution of the feed; size of membrane slot/pore; interfacial tension between continuous and dispersed phase and permeate flux rate. This idea can be used for permeate size distributions of crude oil obtained from various locations and dispersed in different continuous phases. The concept of predicting permeates size distributions can also be applied to the filtration of other deforming materials like yeast and stem cells. 
Table 2 shows the predicted mass of $29^{\circ}$ API and $32{ }^{\circ}$ API crude oil drops in the permeate at different flux rates. Mass of $29{ }^{\circ}$ API crude oil drops in Oil Field Effluent Water and in Bair Aquifer water is reported as 1.5 and 1 ppm respectively [26]. Similarly, mass of crude oil (32 ${ }^{\circ} \mathrm{API}$ ) in Bair Aquifer Water and Produced Water is 17 and 26 ppm respectively [26]. Using the linear fit approach the mass of crude oil drops in the permeate reduced significantly at different flux rates as can be seen in Table 7.2. Theoretically, the mass of various crude oil (29 and $\left.32{ }^{\circ} \mathrm{API}\right)$ in the permeate is reduced by more than 20 times that to the mass of crude oil in the feed at different flux rates. From the above study it can be concluded that if a stream coming from an oil rig containing $500 \mathrm{ppm}$ of crude oil, can be reduced to $25 \mathrm{ppm}$ of crude oil in the permeate using a $4 \mu \mathrm{m}$ slotted pore membrane.

\section{CONCLUSIONS}

Mainly, drag force $\left(F_{d}\right)$ created by the flow of fluid around drops is responsible for the passage of oil drops through the membrane. While, static force $\left(F_{c x}\right)$ acts in the opposite direction to the drag force $\left(F_{d}\right)$ and it tries to reject the drops from the membrane. A balance in static and drag force is assumed at the $100 \%$ rejection point. Extrapolating $100 \%$ rejection or cut-off point to the origin of a graph gives a straight line which is referred to as linear fit. The linear fit approach can be used for predicting permeate size distribution of deforming drops such as oil drops. For a given size, permeate size distribution can be obtained by multiplying the fraction of material passed through the membrane to a size distribution of the feed. The approach of predicting permeate size distribution has been demonstrated with a genuine feed size distribution using published data of a Kuwait oil company. Higher mass of oil was obtained at lower interfacial tension $(\sigma)$ due to the fact that higher deformation and passage of drops 
occurred. Similarly, increase in flux rate $\left(v_{0}^{\prime}\right)$ results in increased mass of drops in the permeate. By knowing the feed size distribution, interfacial tension, slot/pore size of the membrane and flux rates, size distribution for permeate can be predicted for crude oil obtained at various oilfields and locations and, therefore, the total concentration of dispersed oil in water. Further work required to apply and validate the model presented in the study for predicting size distribution of deforming drops in the permeate using slotted pore membrane of different slots width.

\section{ACKNOLOGEMENT}

Authors are deeply thankful to KPK UET Peshawar Pakistan and HEC Pakistan for providing funds for the project. Experimental work is carried out at Chemical Engineering department Loughborough University UK; therefore, the authors also wish their gratitude to the department of Chemical Engineering Loughborough University UK for facilitating the experimental work for the study.

\section{LIST OF SYMBOLS}

$F_{c} \quad$ Static force (N)

$F_{d} \quad$ Drag force $(\mathrm{N})$

$h \quad$ Half width of the slot (m)

$k_{w} \quad$ Drag force correction factor

$R_{s p} \quad$ Radius of spherical drop (m)

$v^{\prime} \quad$ Convection velocity of drops towards membrane surface with shear rate applied $\left(\mathrm{m} \mathrm{s}^{-1}\right)$

$v_{i f} \quad$ Inertial lift migration velocity $\left(\mathrm{m} \mathrm{s}^{-1}\right)$ 
$v_{o}^{\prime} \quad$ Convection velocity of drops towards membrane surface without shear rate applied $\left(\mathrm{m} \mathrm{s}^{-1}\right)$

\title{
GREET SYMBOLS
}

\author{
$\sigma \quad$ Interfacial tension $\left(\mathrm{N} \mathrm{m}^{-1}\right)$ \\ $\alpha \quad$ Angle at which slot converges towards inside $\left({ }^{\circ}\right)$ \\ $\rho_{f} \quad$ Density of the fluid $\left(\mathrm{kg} \mathrm{m}^{-3}\right)$ \\ $\dot{\gamma} \quad$ Shear rate $\left(\mathrm{s}^{-1}\right)$ \\ $\eta \quad$ Viscosity of the fluid (Pa s)
}

\section{REFERENCES}

[1] Kosvintsev, S.R.; Sutrisna, P.D.; Cumming, I.W.; Holdich, R.G.; Mason, G. The passage of deforming oil drops through a slotted microfilter. Chem. Eng. Res. Des. 2007, 85(A4), 530-536.

[2] Colman, D.A.; Thew, M.T. Correlation of separation results from light dispersion hydrocyclones, Chem. Eng. Res. Des. 1983, 61(A), 233-240.

[3] Hargreaves, J.H.; Silvester, R.S.; Computational fluid dynamics applied to the analysis of deoiling hydrocyclone performance, Trans. I. Chem. E. 1990, 68, 365-383.

[4] Wolbert, D.; Ma, B.F.; Aurelle, Y.; Seureau, J. Efficiency estimation of liquid-liquid hydrocyclones using trajectory analysis, AIChE J. 1995, 41 (6), 1395-1401.

[5] Shu, W.; Liangyin, C.; Wenmei, C. Fouling-resistant composite membranes for separation of oil-in-water micro-emulsions. Chin. J. Chem. Eng. 2006, 14(1), 37-45. 
[6] Lin, S.H.; Lan, W.J. Waste oil/water treatment by membrane processes. J. Hazard. Mater. 1998, 59, 189-199.

[7] Lipp, P.; Lee, C.H.; Fane, A.G.; Fell, C.J.D. A fundamental study of ultrafiltration of oilwater emulsions. J. Membr. Sci. 1988, 36, 161-177.

[8] Pan, Y.; Wang, W.; Wang, T.; Yao, P. Fabrication of carbon membrane and microfiltration of oil-in-water emulsion: An investigation on fouling mechanisms. Sep. Purif. Technol. 2007, 57, 388-393.

[9] Gryta, M.; Karakulski, K.; Morawski, A.W. Purification of oily wastewater by hybrid UF/MD. Water Res. 2001, 35, 3665-3669.

[10] Cui, J.; Zhang, X.; Liu, H.; Liu, S.; Yeung, K.L. Preparation and application of zeolite/ceramic microfiltration membranes for treatment of oil contaminated water. J. Membr. Sci. 2008, 325, 420-426.

[11] Scott, K.; Adhamy, A.; Atteck, W.; Davidson, C. Crossflow microfiltration of organic/water suspensions. Water Res. 1994, 28(1), 137-145.

[12] Mueller, J.; Cen , Y.; Davis, R.H. Crossflow microfiltration of oily water. Membr. Sci. $1997,129,221-235$.

[13] Kuiper, S.; Rijn, C.J.M.; Nijdam, W.; Elwenspoek, M.C. Development and applications of very high flux microfiltration membranes. J. Membr. Sci. 1998, 150, 1-8.

[14] Ho, C.C.; Zydney, A.L. Effect of membrane pore geometry on fouling behaviour during yeast cell microfiltration. J. Membr. Sci. 2006, 285, 334-342. 
[15] Ullah, A.; Holdich, R.G.; Naeem, M.; Starov, V.M. Stability and deformation of oil droplets during microfiltration on a slotted pore membrane. J. Membr. Sci. 2012, 401$402,118-124$.

[16] Ullah, A.; Naeem, M.; Holdich, R.G.; Starov, V.M.; Semenov, S. Microfiltration of deforming droplets. Prog. Colloid Polym. Sci. 2012, 139, 107-110.

[17] Ullah, A.; Holdich, R.G.; Naeem, M.; Starov, V.M. Shear enhanced microfiltration and rejection of crude oil drops through a slotted pore membrane including migration velocities. J. Membr. Sci. 2012, 421-422, 69-74.

[18] Ullah, A.; Starov, V.M.; Naeem, N.; Holdich, R.G. Microfiltration of deforming oil droplets on a slotted pore membrane and sustainable flux rates. J. Membr. Sci. 2011, $382,271-277$.

[19] Ullah, A. Starov, V.M.; Naeem, M.; Holdich, R.G.; Semenov, S. Filtration of suspensions using slit pore membranes. Sep. Purif. Technol. 2013, 103, 180-186.

[20] Sarrade, S.; Schrive, L.; Gourgouillon, D.; Rios, G.M. Enhanced filtration of organic viscous liquids by supercritical $\mathrm{CO}_{2}$ addition and fluidification. Application to used oil regeneration. Sep. Purif. Technol. 2001, 25, 315-321.

[21] Jaffrin, M.Y. Dynamic shear-enhanced filtration: A review of rotating disks, rotating membranes, and vibrating systems. J. Membr. Sci. 2008, 324, 7-25.

[22] Soubiran, J.; Sherwood, J.D. Bubble motion in a potential flow within a Venturi. Int. J. Multiphase Flow 2000, 26, 1771-1796. 
[23] Hudson, S.D. Wall migration and shear-induced diffusion of fluid drops in emulsion. Phys. Fluids 2003, 15, 1106-1113.

[24] Belfort, G.; Davis, R.D.; Zydney, A.L. The behaviour of suspensions and macromolecular solutions in cross-flow microfiltration. J. Membr. Sci. 1994, 96, 1-58.

[25] Gomaa, H.G.; Rao, S. Analysis of flux enhancement at oscillating flat surface membranes. J. Membr. Sci. 2011, 374, 59-66.

[26] Alanezi, Y.H.D. Cross-flow microfiltration of oil from synthetic produced water. Ph.D. Thesis, Loughborough University, UK, 2009. 


\section{LIST OF TABLES}

Table 1 Reported size distribution of crude oil (29 and $\left.32{ }^{\circ} \mathrm{API}\right)$ drops per $0.1 \mathrm{ml}$ sample in various continuous phases provided by a Kuwait oil company.

Table 2 Predicted mass of permeate (ppm) of various crude drops in different continuous phases at different flux rates and the feed size distribution data is reported by a Kuwait company. 
Table 1 Reported size distribution of crude oil (29 and $\left.32{ }^{\circ} \mathrm{API}\right)$ drops per $0.1 \mathrm{ml}$ sample in various continuous phases provided by a Kuwait oil company.

\begin{tabular}{|c|c|c|c|c|}
\hline $\begin{array}{l}\text { Drop } \\
\text { size } \\
(\mu \mathrm{m})\end{array}$ & $\begin{array}{l}\text { Number of }\left(29{ }^{\circ} \mathrm{API}\right) \text { per } \\
0.1 \mathrm{ml} \text { of sample in Bair } \\
\text { Aquifer water }\end{array}$ & $\begin{array}{l}\text { Number of drops per (29 } \\
\text { oAPI) per } 0.1 \text { ml of } \\
\text { sample in oil field } \\
\text { effluent water }\end{array}$ & $\begin{array}{l}\text { Number of drops per } \\
(32 \text { oPPI) per } 0.1 \mathrm{ml} \text { of } \\
\text { sample in Bair Aquifer } \\
\text { water }\end{array}$ & $\begin{array}{l}\text { Number of drops } \\
\left(32{ }^{\circ} \mathrm{API}\right) \text { per } 0.1 \mathrm{ml} \\
\text { of sample in } \\
\text { Produced water }\end{array}$ \\
\hline 1.5 & 7566 & 3519 & - & - \\
\hline 2 & 3298 & 1400 & 22511 & 46352 \\
\hline 3 & 745 & 576 & 21622 & 23841 \\
\hline 5 & 117 & 175 & 1899 & 2219 \\
\hline 8 & 22 & 50 & 170 & 320 \\
\hline 10 & 5 & 4 & 79 & 150 \\
\hline 12 & 1 & 16 & 49 & 71 \\
\hline 15 & 0 & 7 & 18 & 22 \\
\hline 20 & 0 & 0 & 4 & 4 \\
\hline
\end{tabular}


Table 2 Predicted mass of permeate (ppm) of various crude drops in different continuous phases at different flux rates and the feed size distribution data is reported by a Kuwait company.

\begin{tabular}{|c|c|c|c|c|}
\hline$\left(1 \mathrm{~m}^{-2} \mathrm{hr}^{-1}\right)$ & $\begin{array}{l}\text { Mass in permeate of } \\
\left.\text { crude oil ( } 29^{\circ} \mathrm{API}\right) \\
\text { in Oil Field Effluent } \\
\text { Water (ppm) }\end{array}$ & $\begin{array}{l}\text { Mass in permeate of } \\
\left.\text { crude oil (29 }{ }^{\circ} \text { API }\right) \\
\text { drops in Bair Aquifer } \\
\text { Water (ppm) }\end{array}$ & $\begin{array}{l}\text { Mass in permeate of } \\
\text { crude oil ( } 32 \text { oAPI }) \\
\text { drops in Bair Aquifer } \\
\text { Water (ppm) }\end{array}$ & $\begin{array}{l}\text { Mass in permeate } \\
\text { of crude oil }(32 \\
\text { oAPI) drops in } \\
\text { Produced Water } \\
\text { (ppm) }\end{array}$ \\
\hline 200 & 0.017 & 0.015 & 0.09 & 0.3 \\
\hline 400 & 0.022 & 0.02 & 0.13 & 0.36 \\
\hline 600 & 0.03 & 0.027 & 0.15 & 0.46 \\
\hline
\end{tabular}




\section{LIST OF FIGURES}

Figure 1 provides the drop size distribution of crude oil from North Sea operating companies $\left.\left(22,27,30^{\circ} \mathrm{API}\right)\right)$ in terms of mass of oil per $2 \mathrm{ml}$ of feed measured by the Coulter Multisizer.

Figure 2 (a) Predicted and experimental size distributions by mass of crude oil (22 ${ }^{\circ} \mathrm{API}$ ) drops in terms of mass of oil per $2 \mathrm{ml}$ of feed by the Coulter Multisizer, provided by North Sea operating companies without shear rate, reducing $400 \mathrm{ppm}$ in the feed into 16, 19 and $21 \mathrm{ppm}$ at 2000, 4000 and $6000 \mathrm{l} \mathrm{m}^{-2} \mathrm{hr}^{-1}$ respectively. Predicted point mean data came from the 'linear fit' approach.

Figure 2 (b) Predicted and experimental size distributions by mass of crude oil (27 ${ }^{\circ} \mathrm{API}$ ) drops in terms of mass of oil per $2 \mathrm{ml}$ of feed measured by the Coulter Multisizer, provided by North Sea operating companies without shear rate, reducing $400 \mathrm{ppm}$ in the feed into 18, 22 and $24 \mathrm{ppm}$ in the permeate at 2000, 4000 and $6000 \mathrm{l} \mathrm{m}^{-2} \mathrm{hr}^{-1}$ respectively.

Figure 2 (c) Predicted and experimental size distributions by mass of crude oil (30 ${ }^{\circ} \mathrm{API}$ ) drops in terms of mass of oil per $2 \mathrm{ml}$ of feed measured by the Coulter Multisizer, provided by North Sea operating companies without shear rate, reducing $400 \mathrm{ppm}$ in the feed into 21,24 and $26 \mathrm{ppm}$ in the permeate at 400, 600 and $1000 \mathrm{l} \mathrm{m}^{-2} \mathrm{hr}^{-1}$ respectively.

Figure 3 (a) Predicted and experimental size distributions of crude oil (30 $\left.{ }^{\circ} \mathrm{API}\right)$ drops in terms of mass of oil per $2 \mathrm{ml}$ of feed measured by the Coulter Multisizer, provided by North Sea operating companies with $10,000 \mathrm{~s}^{-1}$ shear rate, reducing $400 \mathrm{ppm}$ in the feed into 4, 6 and 8 ppm in the permeate at 400, 600 and $1000 \mathrm{l} \mathrm{m}^{-2} \mathrm{hr}^{-1}$ respectively. 
Figure 3 (b) Predicted and experimental size distributions of crude oil (30 $\left.{ }^{\circ} \mathrm{API}\right)$ drops in terms of mass of oil per $2 \mathrm{ml}$ of feed measured by the Coulter Multisizer, provided by North Sea operating companies with $8000 \mathrm{~s}^{-1}$ shear rate, and reducing $400 \mathrm{ppm}$ in the feed into 7, 9, $10 \mathrm{ppm}$ in the permeate at 400, 600 and $1000 \mathrm{l} \mathrm{m}^{-2} \mathrm{hr}^{-1}$ in the permeate respectively.

Figure 4 (a) Feed size distributions of crude oil from Kuwait crude oil operating company (29 $\left.{ }^{\circ} \mathrm{API}\right)$.

Figure 4 (b) Feed size distributions of crude oil from Kuwait crude oil operating company $\left(32^{\circ} \mathrm{API}\right)$.

Figure 5 (a) Prediction of permeate size distributions of crude oil drops (29 ${ }^{\circ} \mathrm{API}$ ) in Oil Field Effluent Water, provided by Kuwait oil company at different flux rates without shear rate applied.

Figure 5 (b) Prediction of permeate size distributions of crude oil drops (29 $\left.{ }^{\circ} \mathrm{API}\right)$ in Bair Aquifer Water, provided by Kuwait oil company at different flux rates without shear rate applied.

Figure 5 (c) Prediction of permeate size distributions of crude oil drops (32 $\left.{ }^{\circ} \mathrm{API}\right)$ in Bair Effluent Water, provided by Kuwait oil company at different flux rates without shear rate applied.

Figure 5 (d) Prediction of permeate size distributions of crude oil drops (32 $\left.{ }^{\circ} \mathrm{API}\right)$ in Produced Water, provided by Kuwait oil company at different flux rates without shear rate applied. 


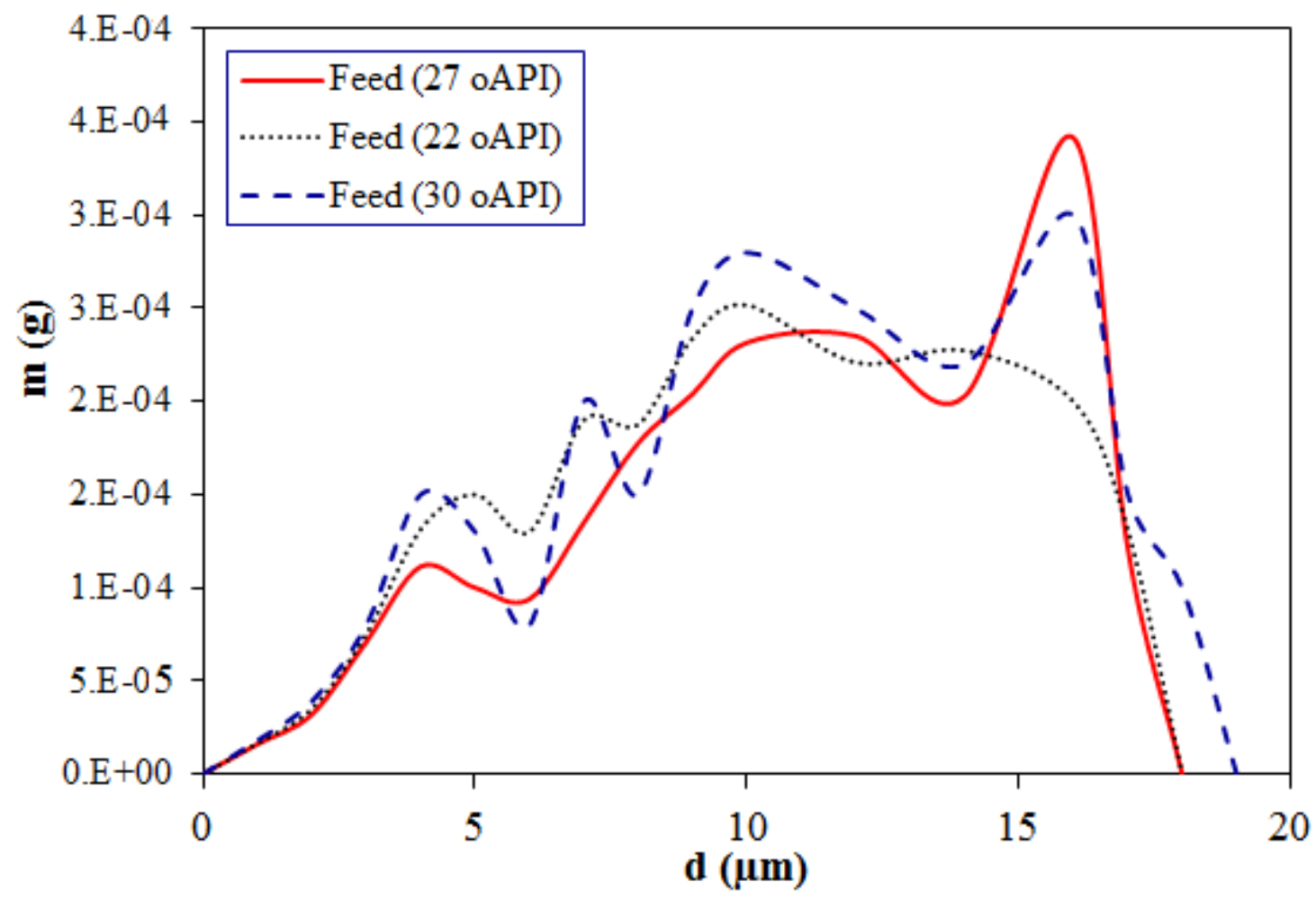

Figure 1 provides the drop size distribution of crude oil from North Sea operating companies $\left.\left(22,27,30^{\circ} \mathrm{API}\right)\right)$ in terms of mass of oil per $2 \mathrm{ml}$ of feed measured by the Coulter Multisizer. 


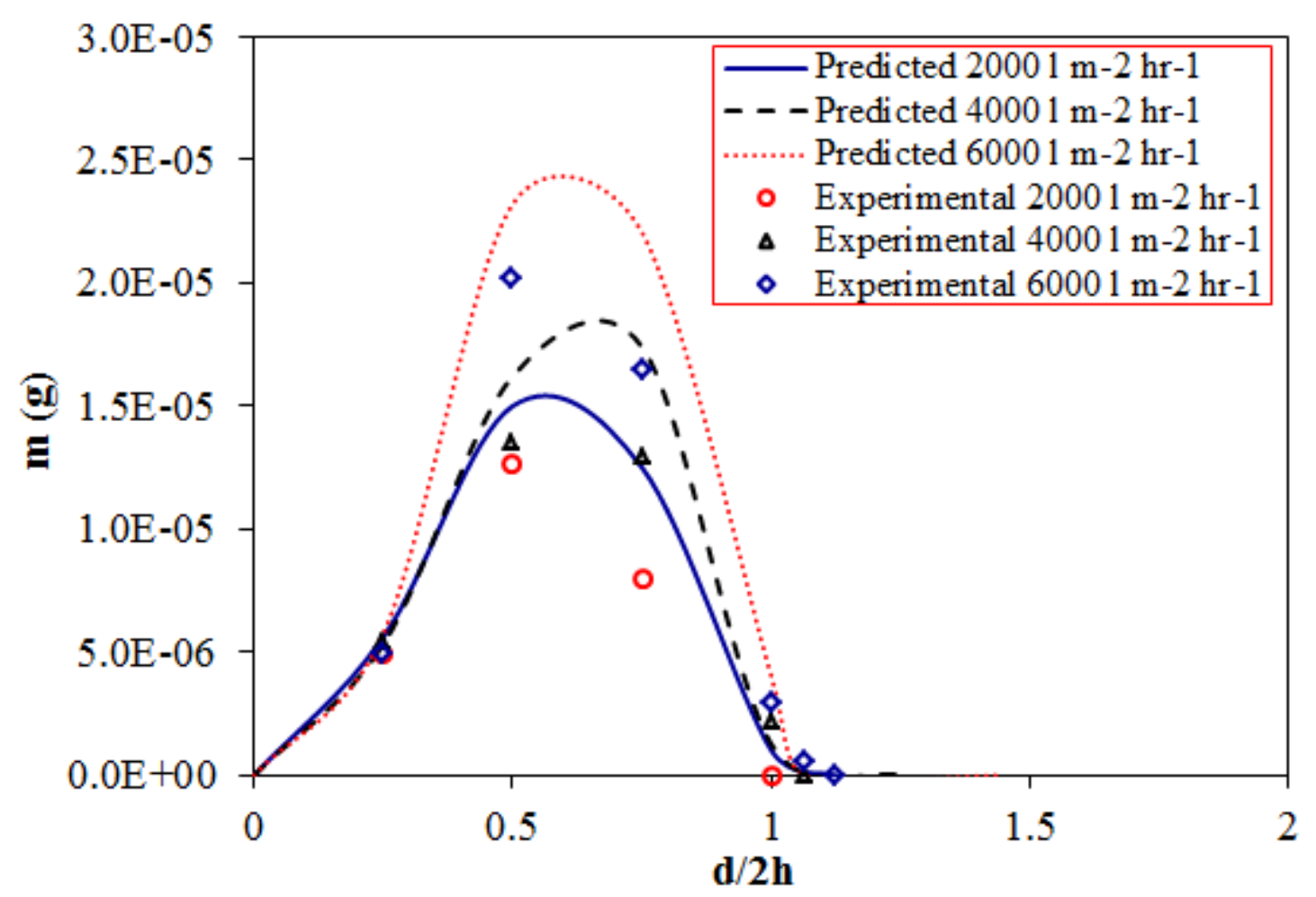

Figure 2 (a) Predicted and experimental size distributions by mass of crude oil (22 $\left.{ }^{\circ} \mathrm{API}\right)$ drops in terms of mass of oil per $2 \mathrm{ml}$ of feed measured by the Coulter Multisizer, provided by North Sea operating companies without shear rate, reducing $400 \mathrm{ppm}$ in the feed into 16, 19 and $21 \mathrm{ppm}$ at 2000, 4000 and $6000 \mathrm{l} \mathrm{m}^{-2} \mathrm{hr}^{-1}$ respectively. Predicted point mean data came from the 'linear fit' approach. 


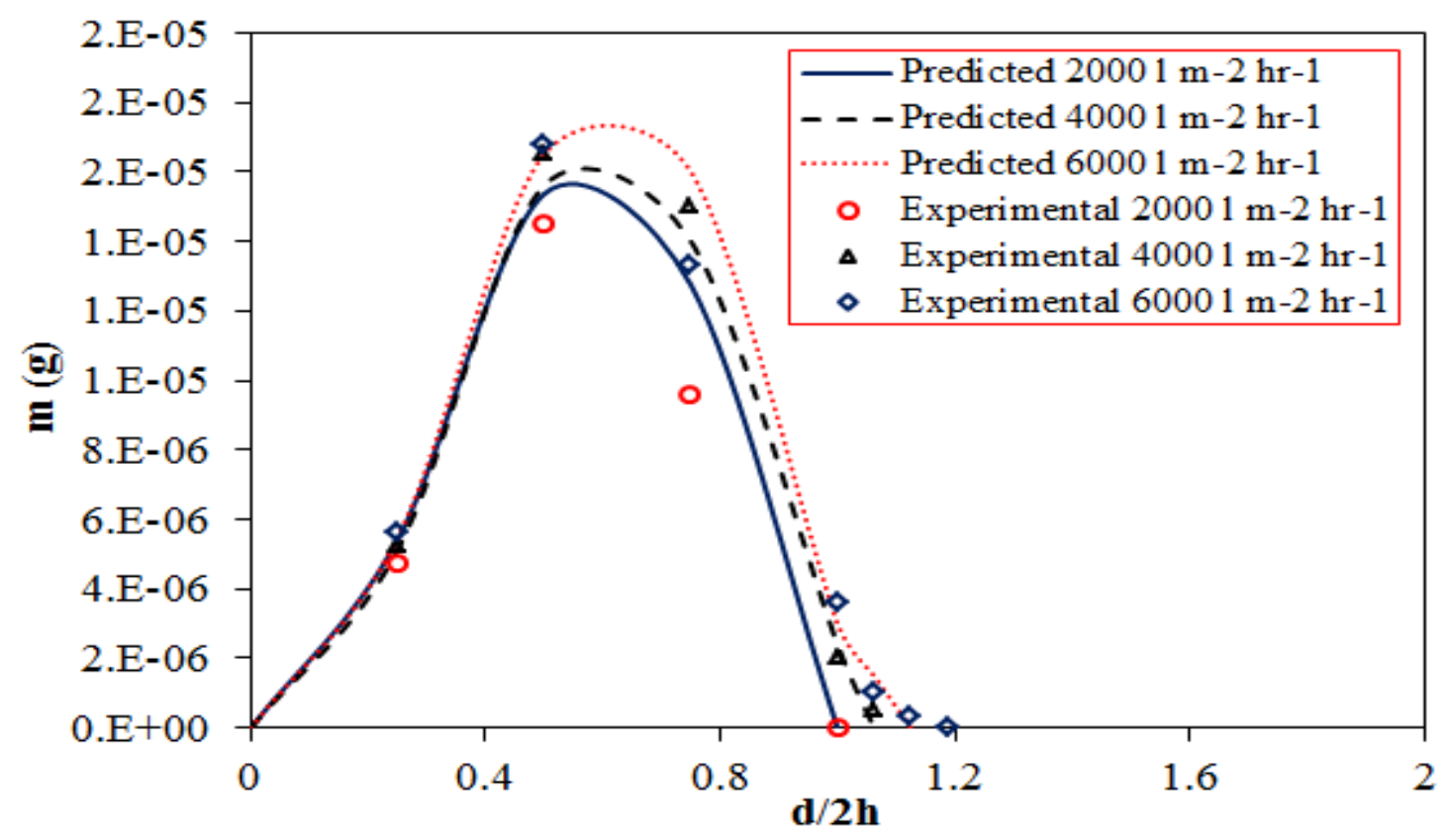

Figure 2 (b) Predicted and experimental size distributions by mass of crude oil (27 ${ }^{\circ} \mathrm{API}$ ) drops in terms of mass of oil per $2 \mathrm{ml}$ of feed measured by the Coulter Multisizer, provided by North Sea operating companies without shear rate, reducing $400 \mathrm{ppm}$ in the feed into 18, 22 and $24 \mathrm{ppm}$ in the permeate at 2000, 4000 and $6000 \mathrm{l} \mathrm{m}^{-2} \mathrm{hr}^{-1}$ respectively. 


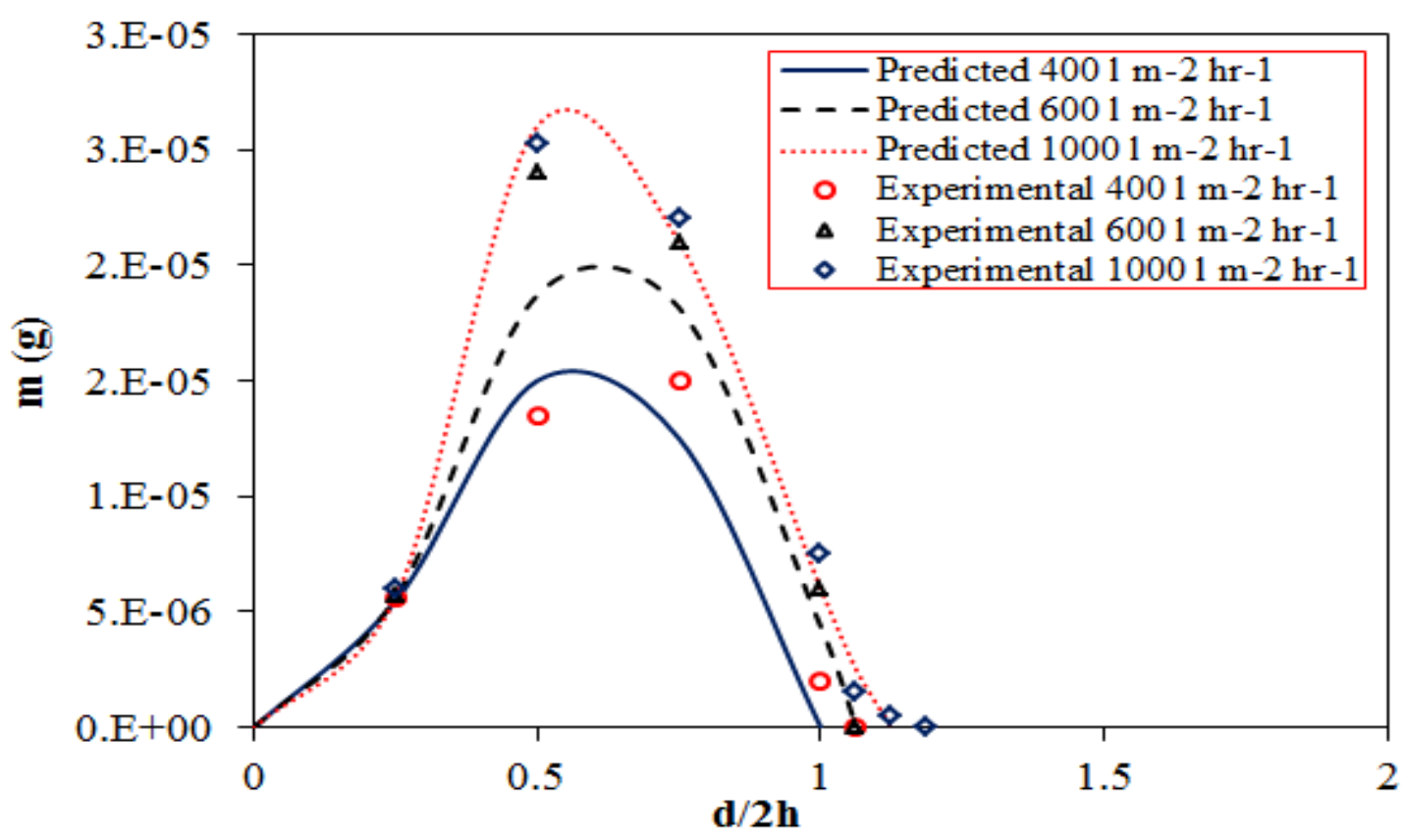

Figure 2 (c) Predicted and experimental size distributions by mass of crude oil (30 ${ }^{\circ} \mathrm{API}$ ) drops in terms of mass of oil per $2 \mathrm{ml}$ of feed measured by the Coulter Multisizer, provided by North Sea operating companies without shear rate, reducing $400 \mathrm{ppm}$ in the feed into 21,24 and $26 \mathrm{ppm}$ in the permeate at 400, 600 and $1000 \mathrm{l} \mathrm{m}^{-2} \mathrm{hr}^{-1}$ respectively. 


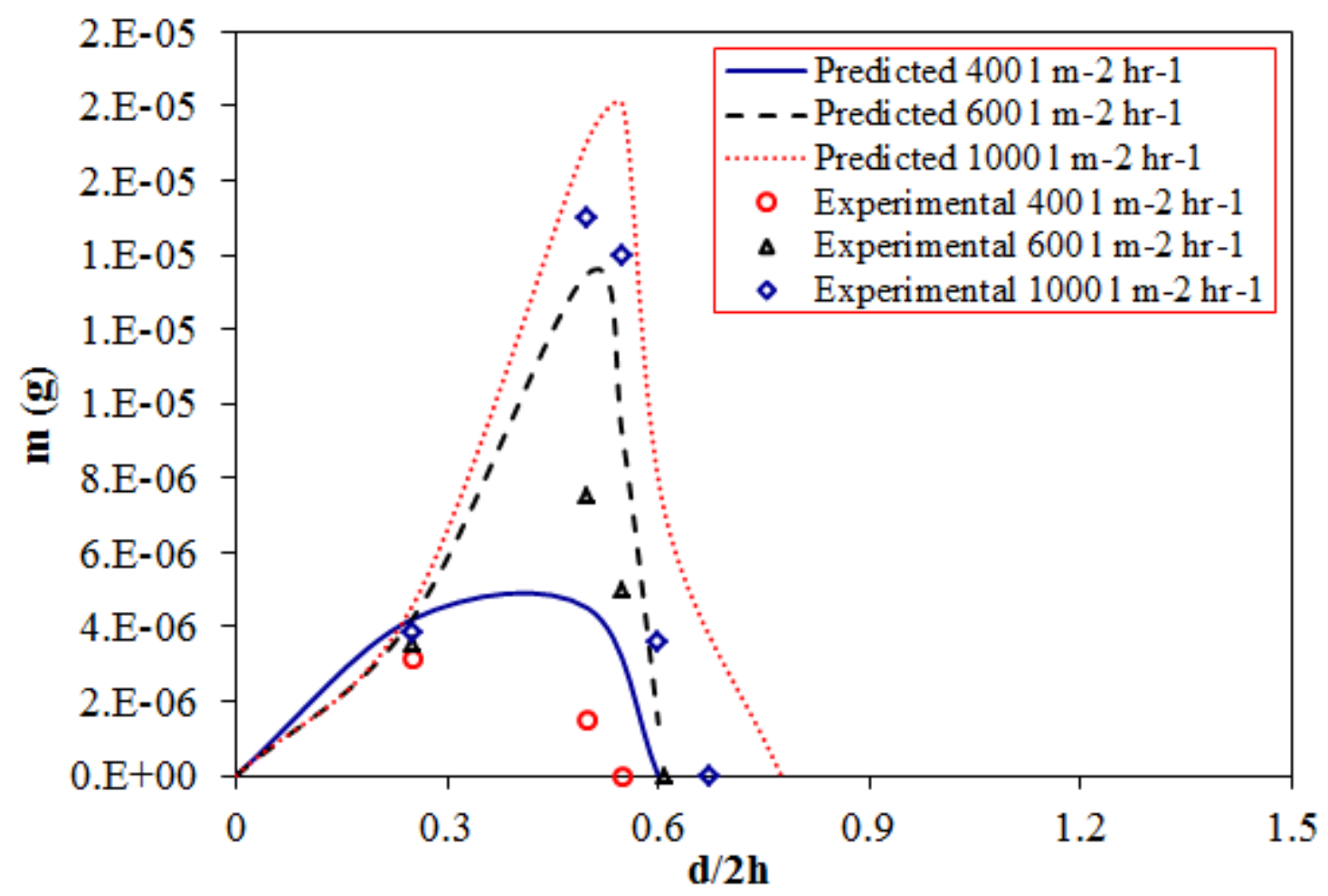

Figure 3 (a) Predicted and experimental size distributions of crude oil (30 $\left.{ }^{\circ} \mathrm{API}\right)$ drops in terms of mass of oil per $2 \mathrm{ml}$ of feed measured by the Coulter Multisizer, provided by North Sea operating companies with $10,000 \mathrm{~s}^{-1}$ shear rate, reducing $400 \mathrm{ppm}$ in the feed into 4, 6 and $8 \mathrm{ppm}$ in the permeate at 400, 600 and $1000 \mathrm{l} \mathrm{m}^{-2} \mathrm{hr}^{-1}$ respectively. 


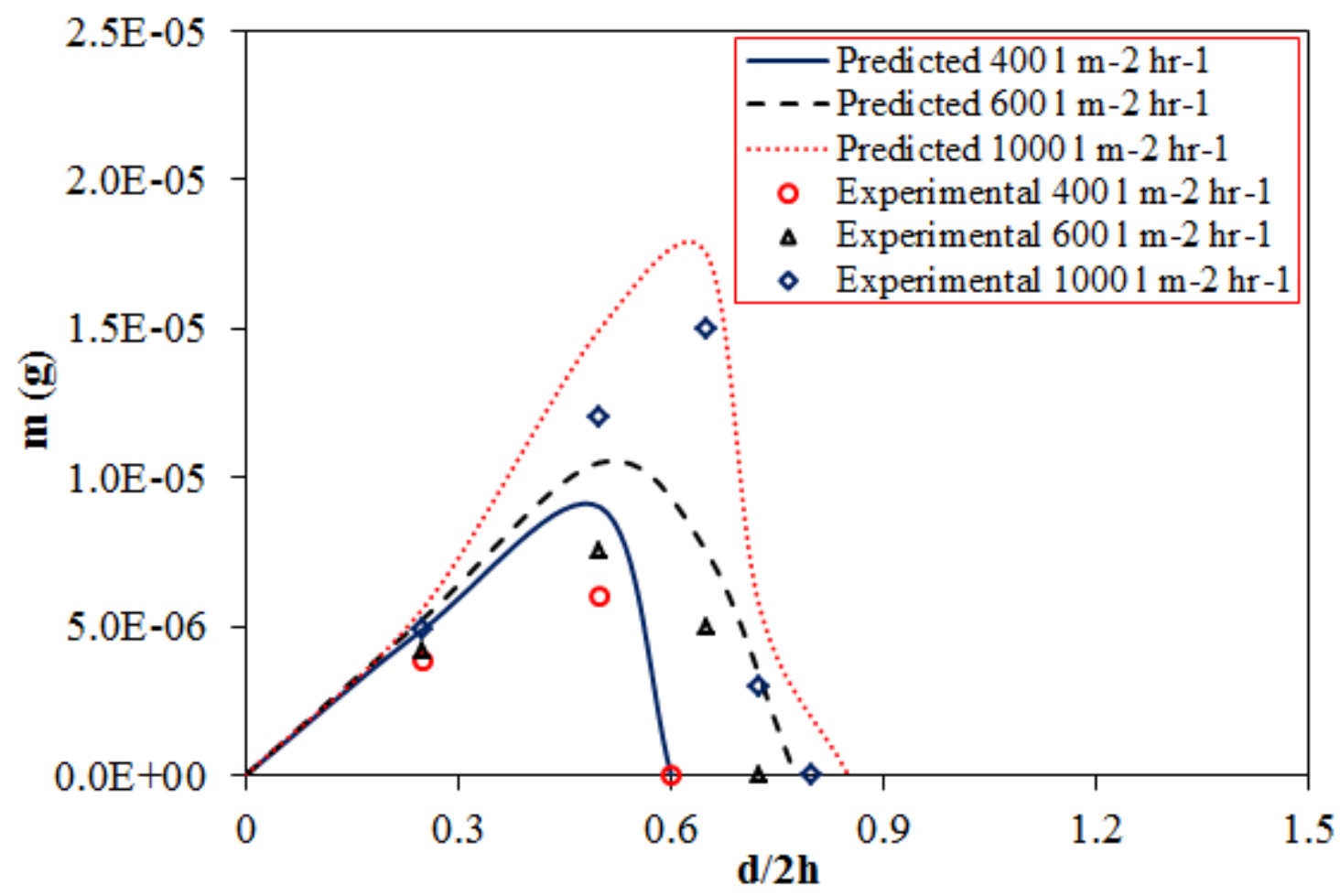

Figure 3 (b) Predicted and experimental size distributions of crude oil (30 $\left.{ }^{\circ} \mathrm{API}\right)$ drops in terms of mass of oil per $2 \mathrm{ml}$ of feed measured by the Coulter Multisizer, provided by North Sea operating companies with $8000 \mathrm{~s}^{-1}$ shear rate, and reducing $400 \mathrm{ppm}$ in the feed into 7, 9, $10 \mathrm{ppm}$ in the permeate at 400, 600 and $1000 \mathrm{l} \mathrm{m}^{-2} \mathrm{hr}^{-1}$ in the permeate respectively. 


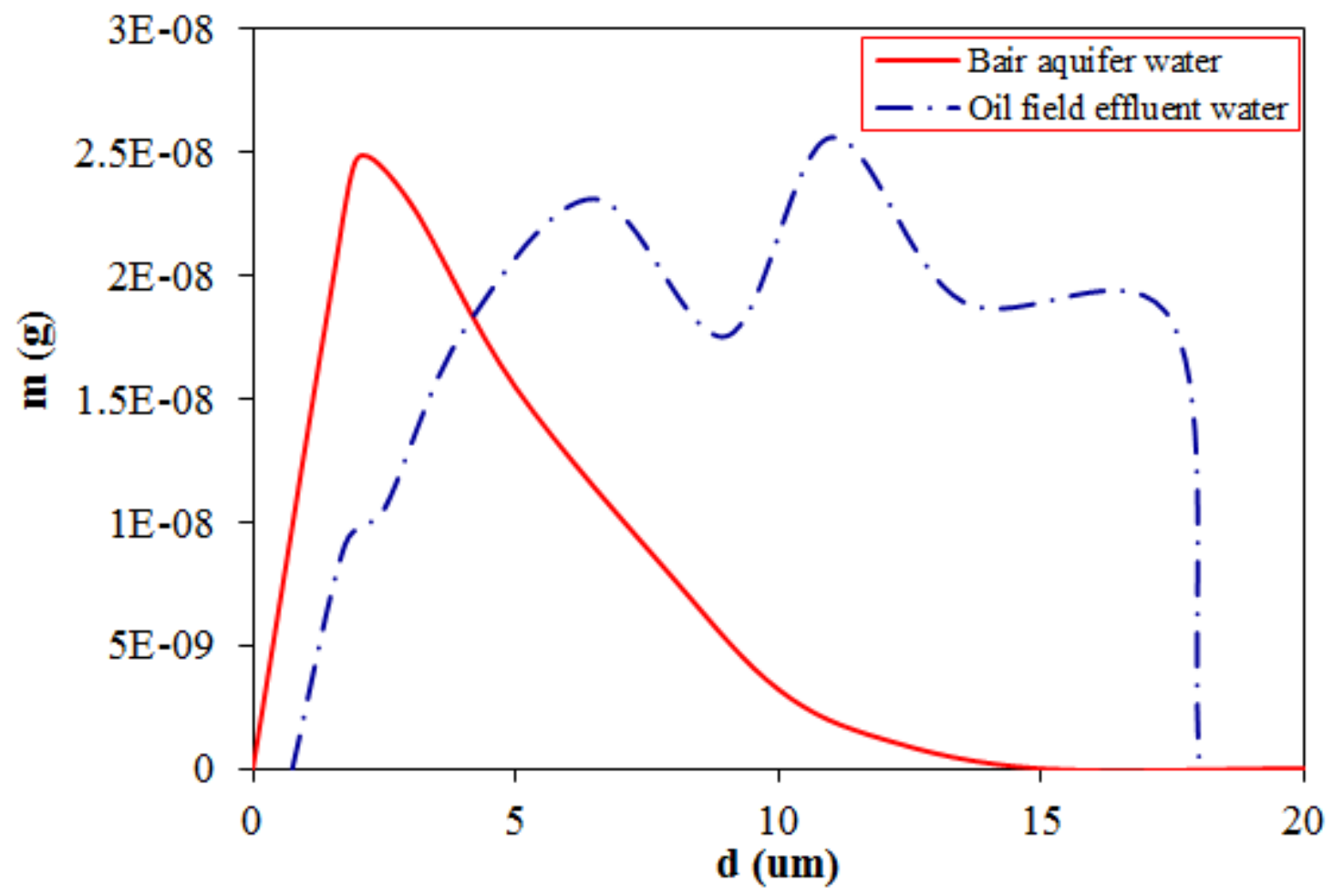

Figure 4 (a) Feed size distributions of crude oil from Kuwait crude oil operating company (29 $\left.{ }^{\circ} \mathrm{API}\right)$. 


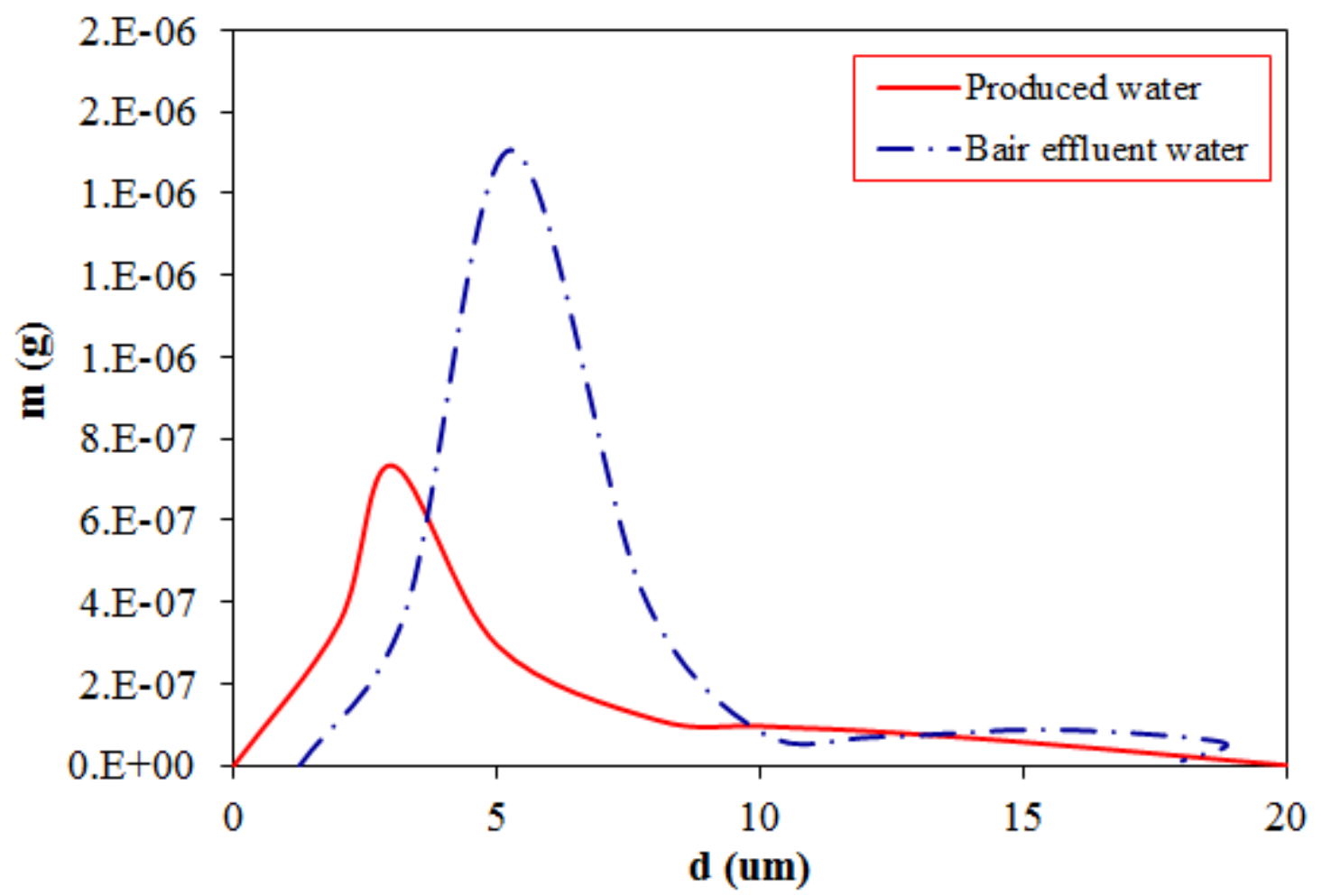

Figure 4 (b) Feed size distributions of crude oil from Kuwait crude oil operating company $\left(32^{\circ} \mathrm{API}\right)$. 


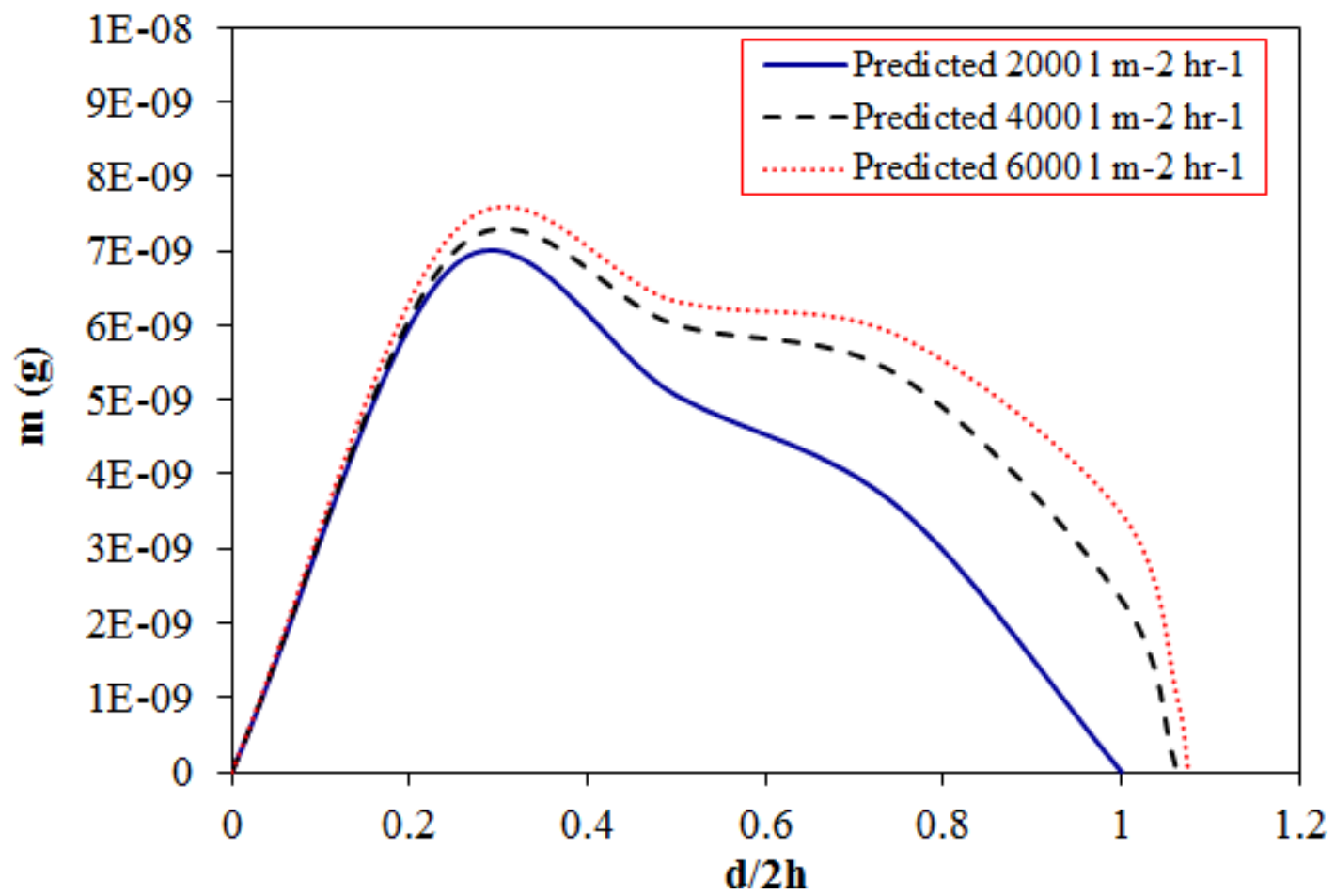

Figure 5 (a) Prediction of permeate size distributions of crude oil drops (29 $\left.{ }^{\circ} \mathrm{API}\right)$ in Oil Field Effluent Water, provided by Kuwait oil company at different flux rates without shear rate applied. 


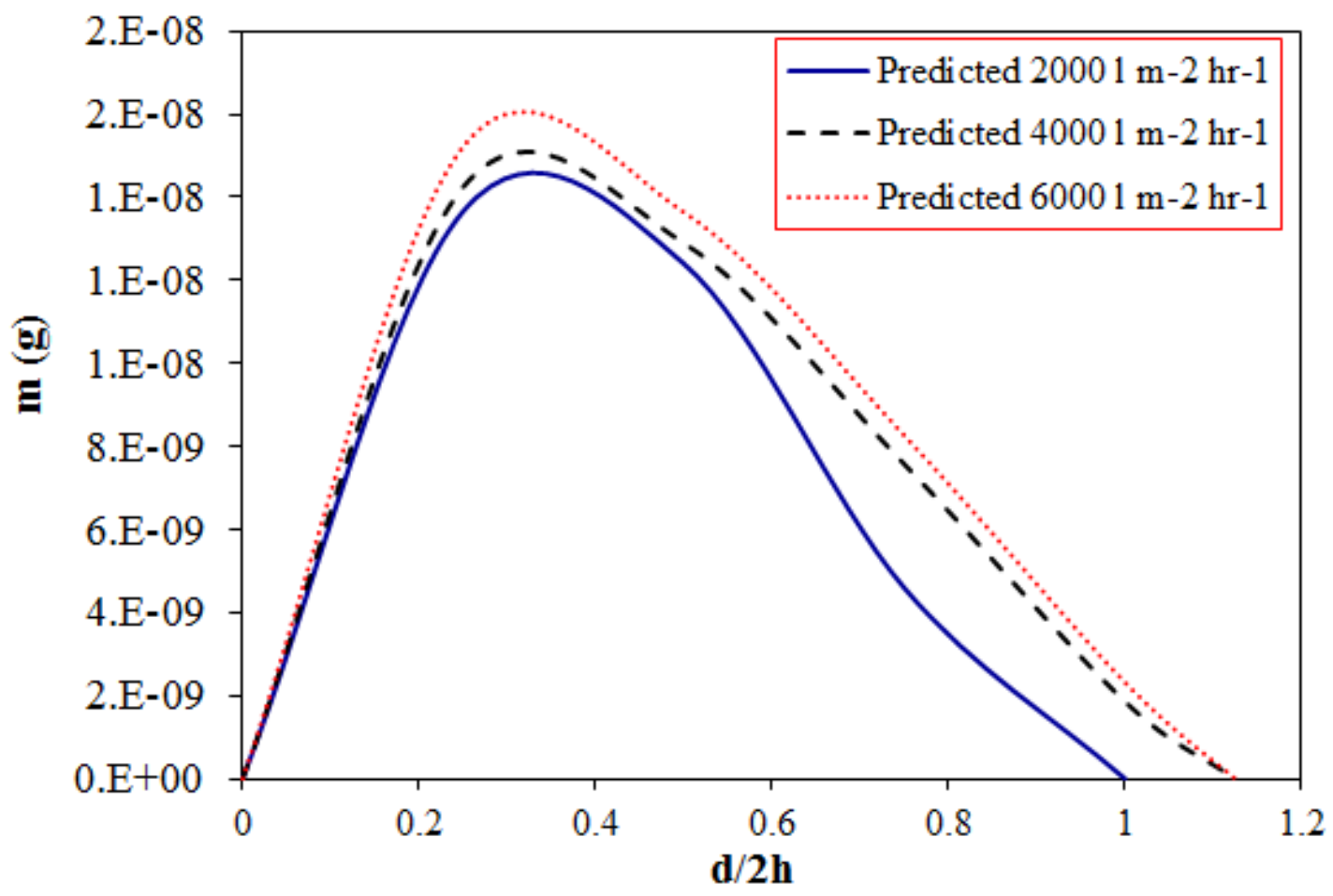

Figure 5 (b) Prediction of permeate size distributions of crude oil drops (29 $\left.{ }^{\circ} \mathrm{API}\right)$ in Bair Aquifer Water, provided by Kuwait oil company at different flux rates without shear rate applied. 


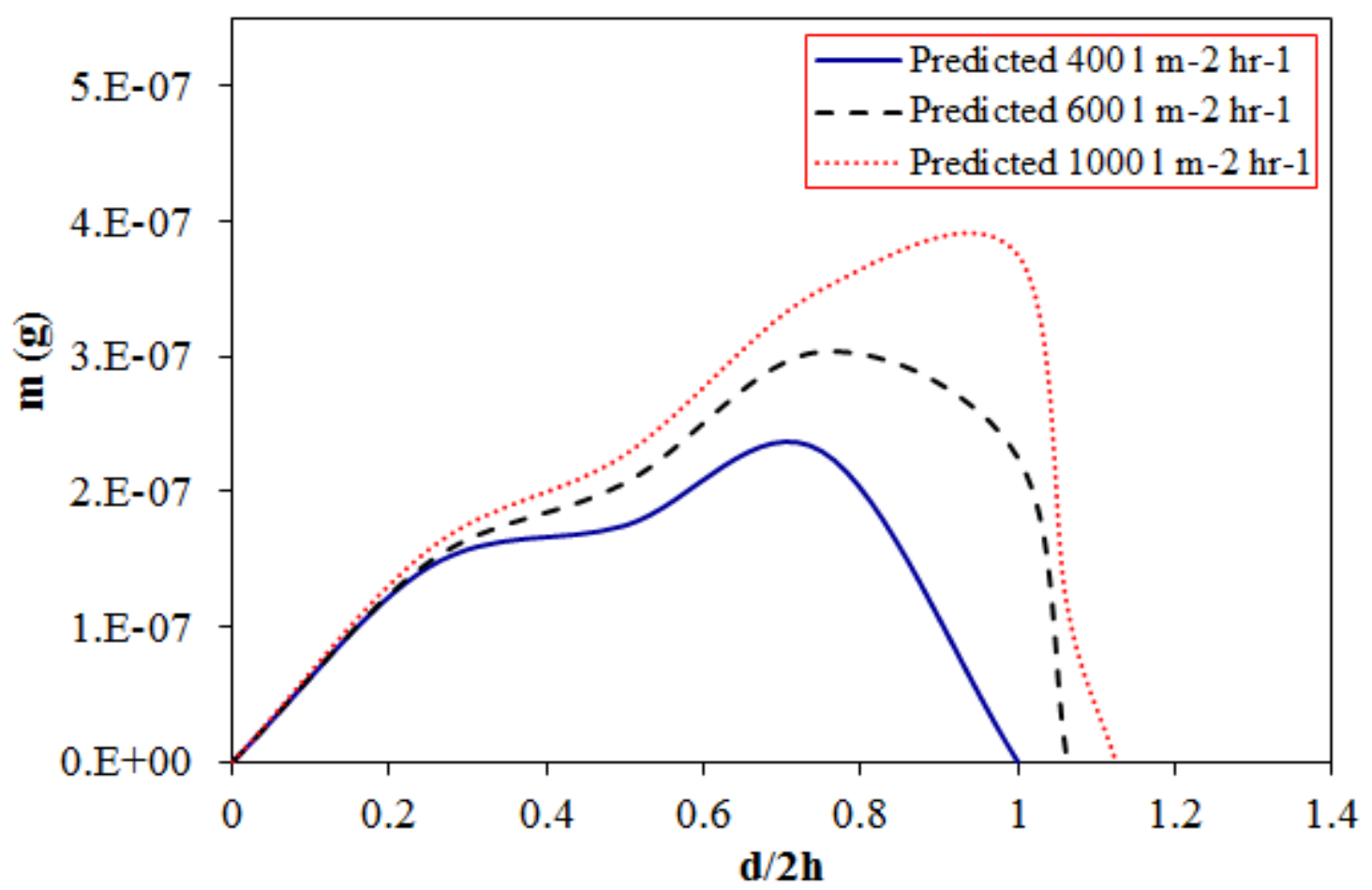

Figure 5 (c) Prediction of permeate size distributions of crude oil drops (32 $\left.{ }^{\circ} \mathrm{API}\right)$ in Bair Effluent Water, provided by Kuwait oil company at different flux rates without shear rate applied. 


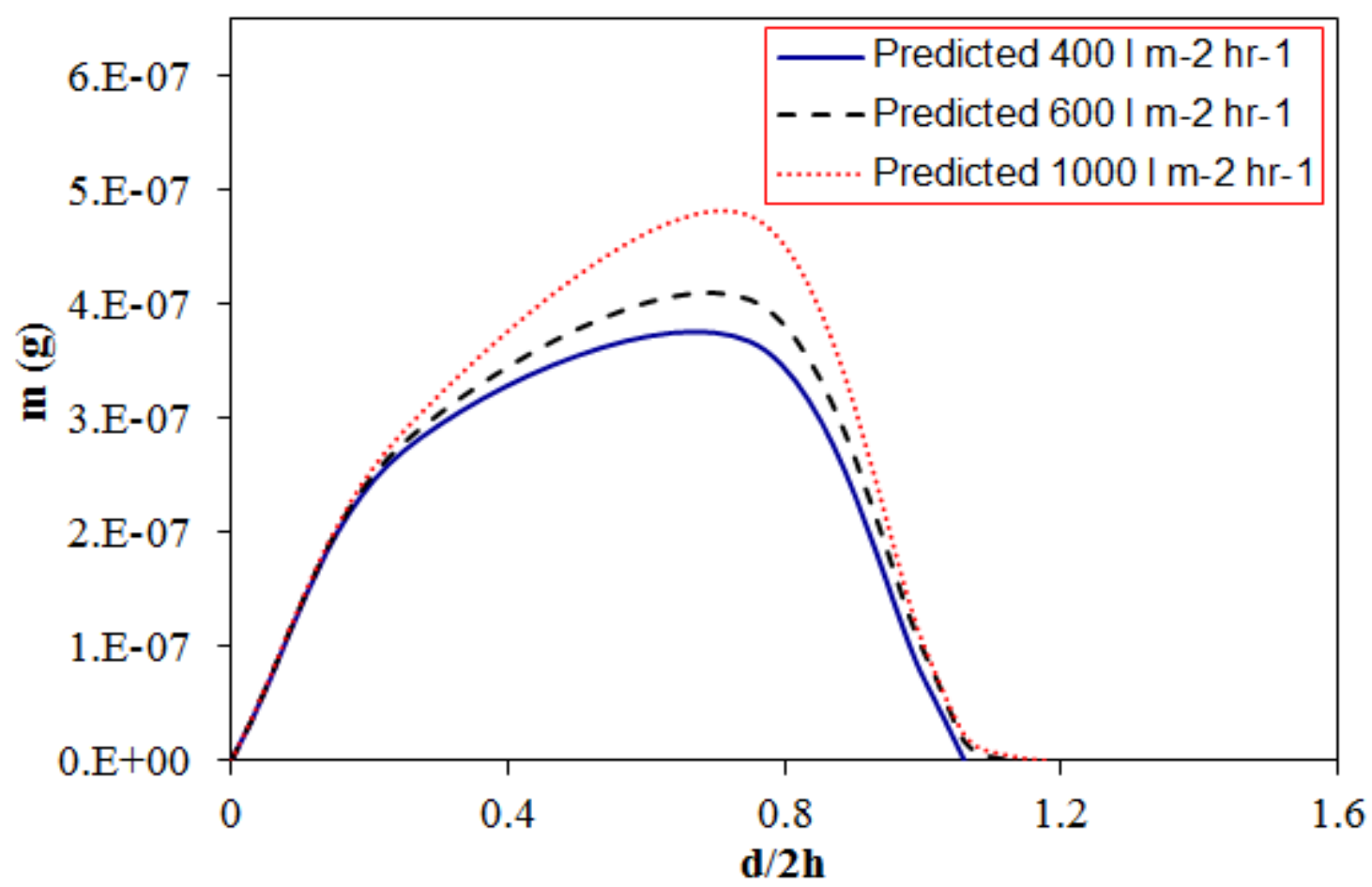

Figure 5 (d) Prediction of permeate size distributions of crude oil drops (32 $\left.{ }^{\circ} \mathrm{API}\right)$ in Produced Water, provided by Kuwait oil company at different flux rates without shear rate applied. 


\section{List of Tables}

Table 1 Reported size distribution of crude oil (29 and $32{ }^{\circ} \mathrm{API}$ ) drops per $0.1 \mathrm{ml}$ sample in various continuous phases provided by a Kuwait oil company.

Table 2 Predicted mass of permeate (ppm) of various crude drops in different continuous phases at different flux rates and the feed size distribution data is reported by a Kuwait company. 
Table 1 Reported size distribution of crude oil ( 29 and $32{ }^{\circ} \mathrm{API}$ ) drops per $0.1 \mathrm{ml}$ sample in various continuous phases provided by a Kuwait oil company.

\begin{tabular}{|c|c|c|c|c|}
\hline $\begin{array}{l}\text { Drop } \\
\text { size } \\
(\mu \mathrm{m})\end{array}$ & $\begin{array}{l}\left.\text { Number of (29 }{ }^{\circ} \mathrm{API}\right) \text { per } \\
0.1 \mathrm{ml} \text { of sample in Bair } \\
\text { Aquifer water }\end{array}$ & $\begin{array}{l}\text { Number of drops per ( } 29 \\
\text { oAPI) per } 0.1 \mathrm{ml} \text { of } \\
\text { sample in oil field } \\
\text { effluent water }\end{array}$ & $\begin{array}{l}\text { Number of drops per } \\
(32 \text { oAPI) per } 0.1 \mathrm{ml} \text { of } \\
\text { sample in Bair Aquifer } \\
\text { water }\end{array}$ & $\begin{array}{l}\text { Number of drops } \\
(32 \text { oAPI) per } 0.1 \mathrm{ml} \\
\text { of sample in } \\
\text { Produced water }\end{array}$ \\
\hline 1.5 & 7566 & 3519 & - & - \\
\hline 2 & 3298 & 1400 & 22511 & 46352 \\
\hline 3 & 745 & 576 & 21622 & 23841 \\
\hline 5 & 117 & 175 & 1899 & 2219 \\
\hline 8 & 22 & 50 & 170 & 320 \\
\hline 10 & 5 & 4 & 79 & 150 \\
\hline 12 & 1 & 16 & 49 & 71 \\
\hline 15 & 0 & 7 & 18 & 22 \\
\hline 20 & 0 & 0 & 4 & 4 \\
\hline
\end{tabular}


Table 2 Predicted mass of permeate (ppm) of various crude drops in different continuous phases at different flux rates and the feed size distribution data is reported by a Kuwait company.

\begin{tabular}{|c|c|c|c|c|}
\hline $\begin{array}{l}\text { Flux rate } \\
\left(1 \mathrm{~m}^{-2} \mathrm{hr}^{-1}\right)\end{array}$ & $\begin{array}{l}\text { Mass in permeate of } \\
\text { crude oil ( } 29 \text { oAPI) } \\
\text { in Oil Field Effluent } \\
\text { Water (ppm) }\end{array}$ & $\begin{array}{l}\text { Mass in permeate of } \\
\text { crude oil }(29 \text { oAPI) } \\
\text { drops in Bair Aquifer } \\
\text { Water (ppm) }\end{array}$ & $\begin{array}{l}\text { Mass in permeate of } \\
\text { crude oil ( } 32 \text { oAPI) } \\
\text { drops in Bair Aquifer } \\
\text { Water (ppm) }\end{array}$ & $\begin{array}{l}\text { Mass in permeate } \\
\text { of crude oil }(32 \\
\text { oAPI) drops in } \\
\text { Produced Water } \\
\text { (ppm) }\end{array}$ \\
\hline 200 & 0.017 & 0.015 & 0.09 & 0.3 \\
\hline 400 & 0.022 & 0.02 & 0.13 & 0.36 \\
\hline 600 & 0.03 & 0.027 & 0.15 & 0.46 \\
\hline
\end{tabular}




\section{List of Figures}

Figure 1 provides the drop size distribution of crude oil from North Sea operating companies $\left.\left(22,27,30^{\circ} \mathrm{API}\right)\right)$ in terms of mass of oil per $2 \mathrm{ml}$ of feed measured by the Coulter Multisizer.

Figure 2 (a) Predicted and experimental size distributions by mass of crude oil (22 $\left.{ }^{\circ} \mathrm{API}\right)$ drops in terms of mass of oil per $2 \mathrm{ml}$ of feed by the Coulter Multisizer, provided by North Sea operating companies without shear rate, reducing $400 \mathrm{ppm}$ in the feed into 16, 19 and $21 \mathrm{ppm}$ at 2000, 4000 and $6000 \mathrm{~m}^{-2} \mathrm{hr}^{-1}$ respectively. Predicted point mean data came from the 'linear fit' approach.

Figure 2 (b) Predicted and experimental size distributions by mass of crude oil (27 ${ }^{\circ} \mathrm{API}$ ) drops in terms of mass of oil per $2 \mathrm{ml}$ of feed measured by the Coulter Multisizer, provided by North Sea operating companies without shear rate, reducing $400 \mathrm{ppm}$ in the feed into 18, 22 and $24 \mathrm{ppm}$ in the permeate at 2000, 4000 and $6000 \mathrm{l} \mathrm{m}^{-2} \mathrm{hr}^{-1}$ respectively.

Figure 2 (c) Predicted and experimental size distributions by mass of crude oil ( $\left.30{ }^{\circ} \mathrm{API}\right)$ drops in terms of mass of oil per $2 \mathrm{ml}$ of feed measured by the Coulter Multisizer, provided by North Sea operating companies without shear rate, reducing $400 \mathrm{ppm}$ in the feed into 21,24 and $26 \mathrm{ppm}$ in the permeate at 400, 600 and $1000 \mathrm{l} \mathrm{m}^{-2} \mathrm{hr}^{-1}$ respectively.

Figure 3 (a) Predicted and experimental size distributions of crude oil (30 $\left.{ }^{\circ} \mathrm{API}\right)$ drops in terms of mass of oil per $2 \mathrm{ml}$ of feed measured by the Coulter Multisizer, provided by North Sea operating companies with $10,000 \mathrm{~s}^{-1}$ shear rate, reducing $400 \mathrm{ppm}$ in the feed into 4, 6 and 8 ppm in the permeate at 400, 600 and $1000 \mathrm{l} \mathrm{m}^{-2} \mathrm{hr}^{-1}$ respectively. 
Figure 3 (b) Predicted and experimental size distributions of crude oil ( $\left.30^{\circ} \mathrm{API}\right)$ drops in terms of mass of oil per $2 \mathrm{ml}$ of feed measured by the Coulter Multisizer, provided by North Sea operating companies with $8000 \mathrm{~s}^{-1}$ shear rate, and reducing $400 \mathrm{ppm}$ in the feed into 7, 9, $10 \mathrm{ppm}$ in the permeate at 400, 600 and $1000 \mathrm{l} \mathrm{m}^{-2} \mathrm{hr}^{-1}$ in the permeate respectively.

Figure 4 (a) Feed size distributions of crude oil from Kuwait crude oil operating company (29 $\mathrm{API})$.

Figure 4 (b) Feed size distributions of crude oil from Kuwait crude oil operating company $\left(32^{\circ} \mathrm{API}\right)$.

Figure 5 (a) Prediction of permeate size distributions of crude oil drops (29 ${ }^{\circ} \mathrm{API}$ ) in Oil Field Effluent Water, provided by Kuwait oil company at different flux rates without shear rate applied.

Figure 5 (b) Prediction of permeate size distributions of crude oil drops (29 ${ }^{\circ} \mathrm{API}$ ) in Bair Aquifer Water, provided by Kuwait oil company at different flux rates without shear rate applied.

Figure 5 (c) Prediction of permeate size distributions of crude oil drops (32 $\left.{ }^{\circ} \mathrm{API}\right)$ in Bair Effluent Water, provided by Kuwait oil company at different flux rates without shear rate applied.

Figure 5 (d) Prediction of permeate size distributions of crude oil drops (32 ${ }^{\circ} \mathrm{API}$ ) in Produced Water, provided by Kuwait oil company at different flux rates without shear rate applied. 


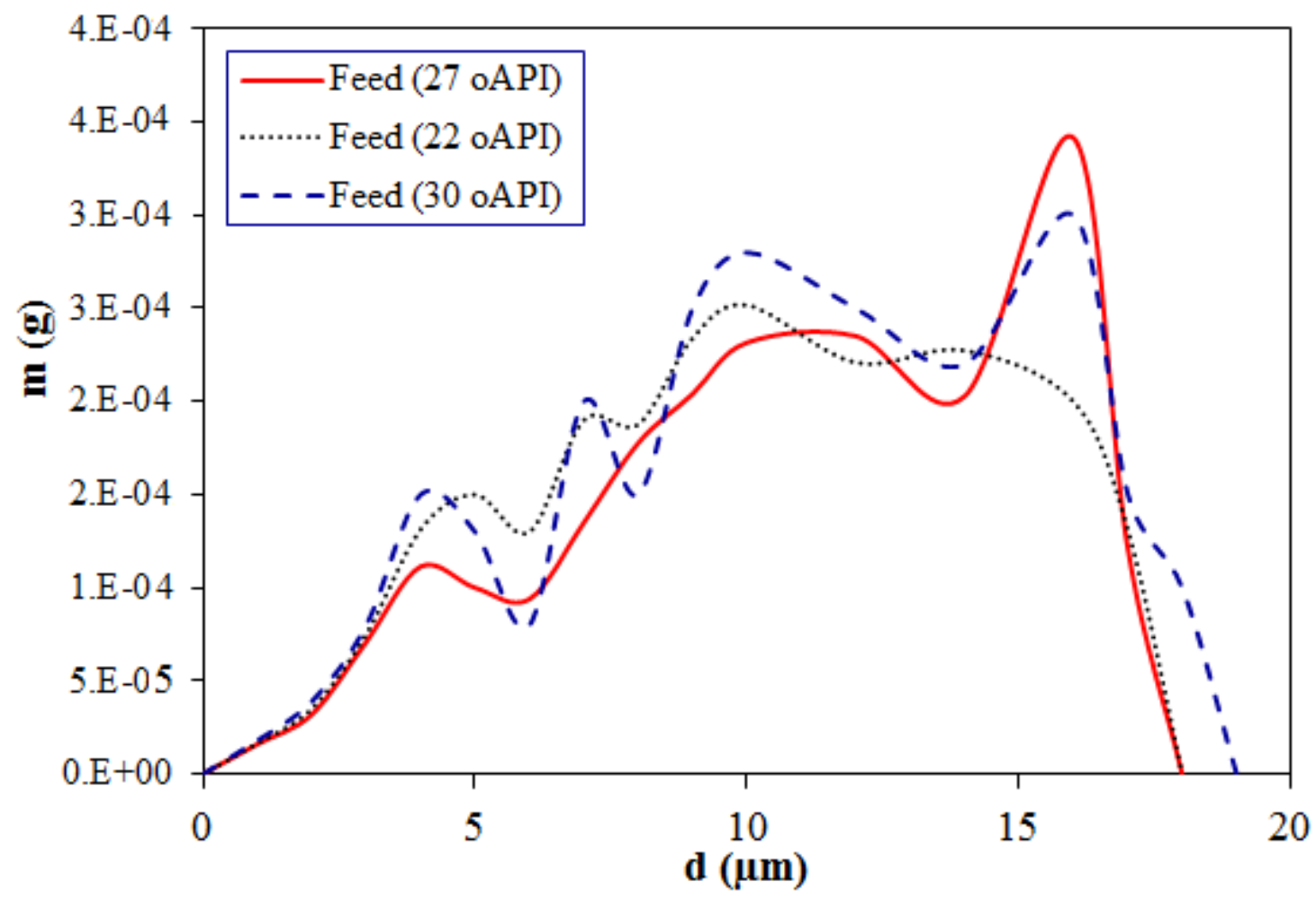

Figure 1 provides the drop size distribution of crude oil from North Sea operating companies $\left.\left(22,27,30^{\circ} \mathrm{API}\right)\right)$ in terms of mass of oil per $2 \mathrm{ml}$ of feed measured by the Coulter Multisizer. 


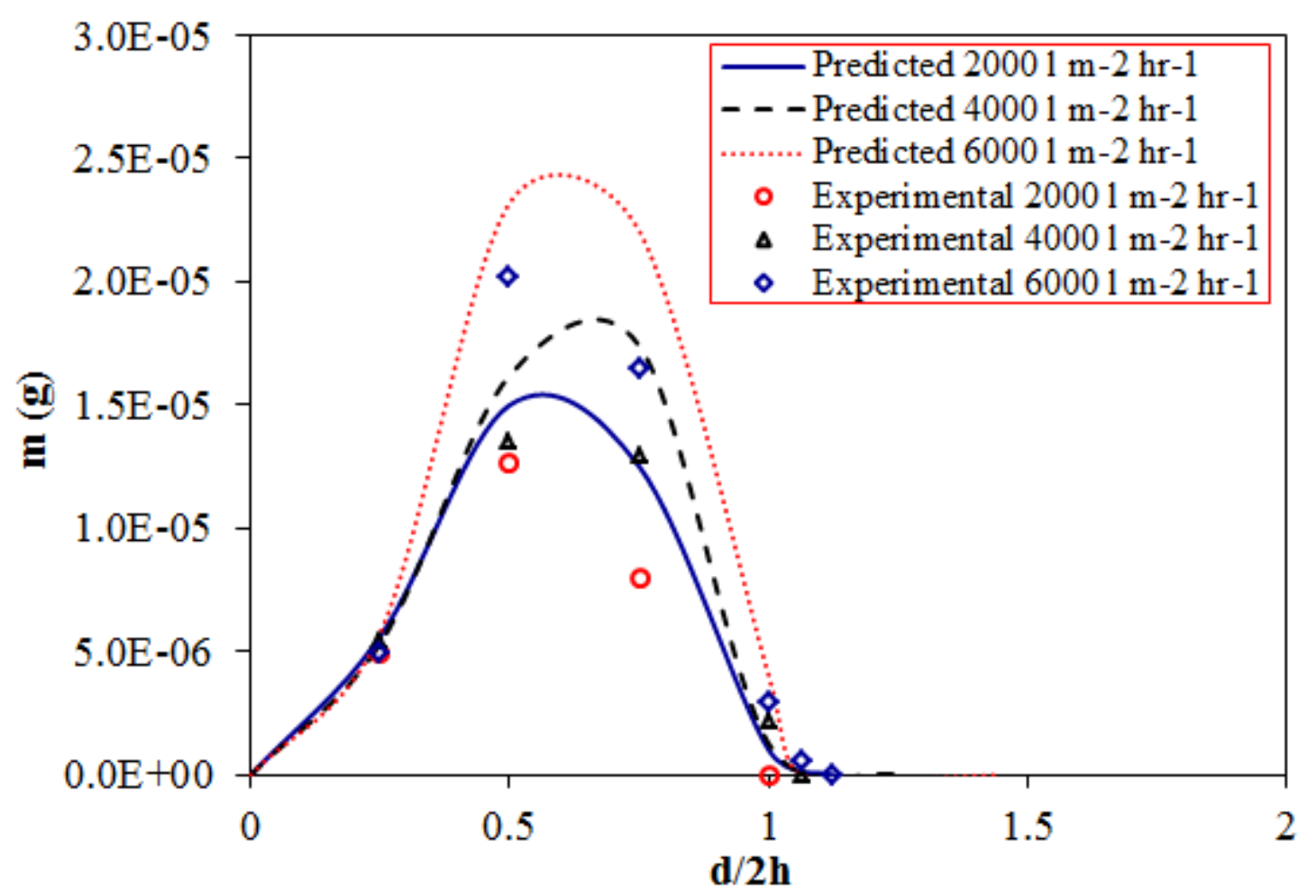

Figure 2 (a) Predicted and experimental size distributions by mass of crude oil (22 $\left.{ }^{\circ} \mathrm{API}\right)$ drops in terms of mass of oil per $2 \mathrm{ml}$ of feed measured by the Coulter Multisizer, provided by North Sea operating companies without shear rate, reducing $400 \mathrm{ppm}$ in the feed into 16, 19 and $21 \mathrm{ppm}$ at 2000, 4000 and $6000 \mathrm{l} \mathrm{m}^{-2} \mathrm{hr}^{-1}$ respectively. Predicted point mean data came from the 'linear fit' approach. 


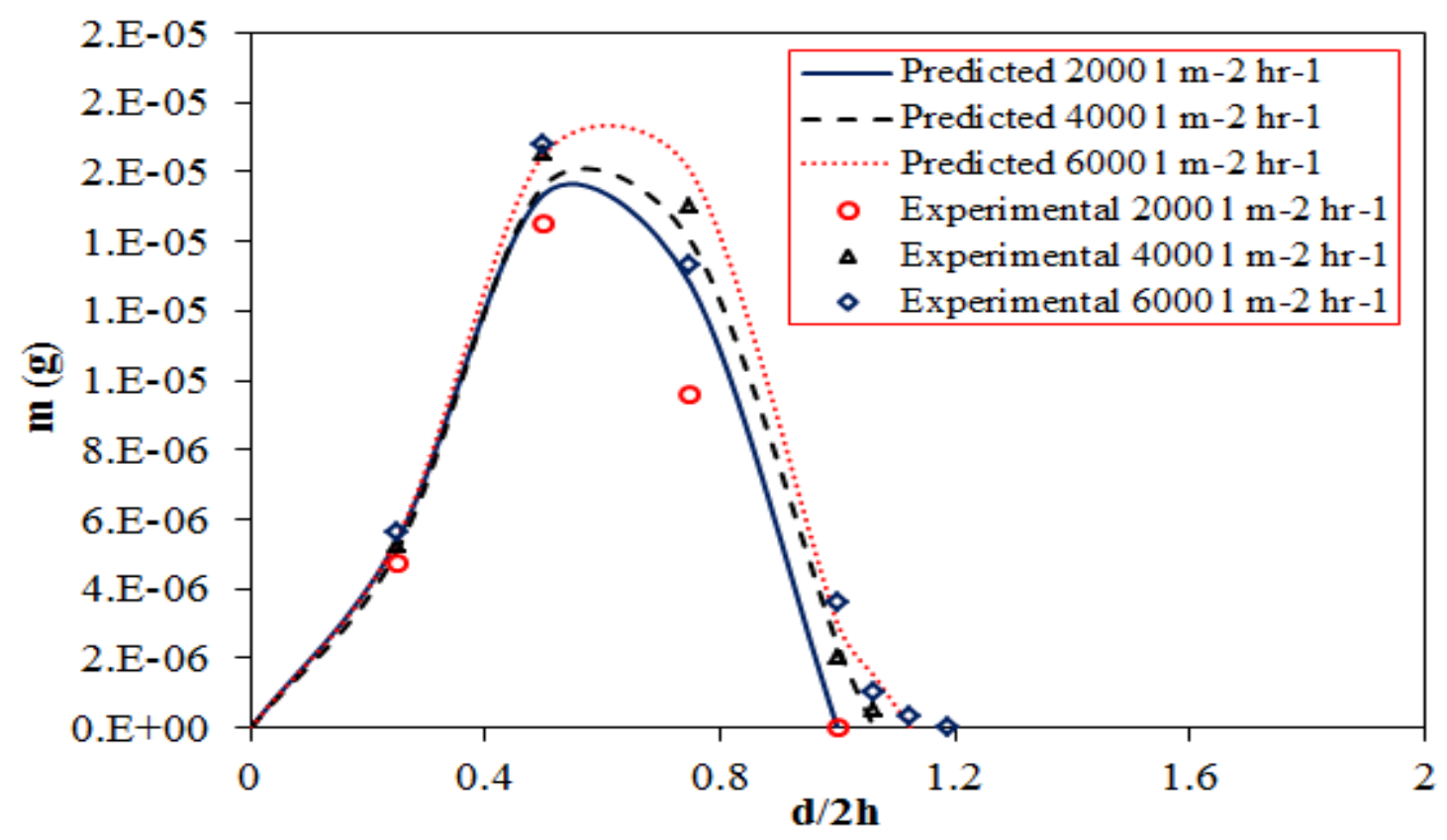

Figure 2 (b) Predicted and experimental size distributions by mass of crude oil (27 ${ }^{\circ} \mathrm{API}$ ) drops in terms of mass of oil per $2 \mathrm{ml}$ of feed measured by the Coulter Multisizer, provided by North Sea operating companies without shear rate, reducing $400 \mathrm{ppm}$ in the feed into 18, 22 and $24 \mathrm{ppm}$ in the permeate at 2000, 4000 and $6000 \mathrm{l} \mathrm{m}^{-2} \mathrm{hr}^{-1}$ respectively. 


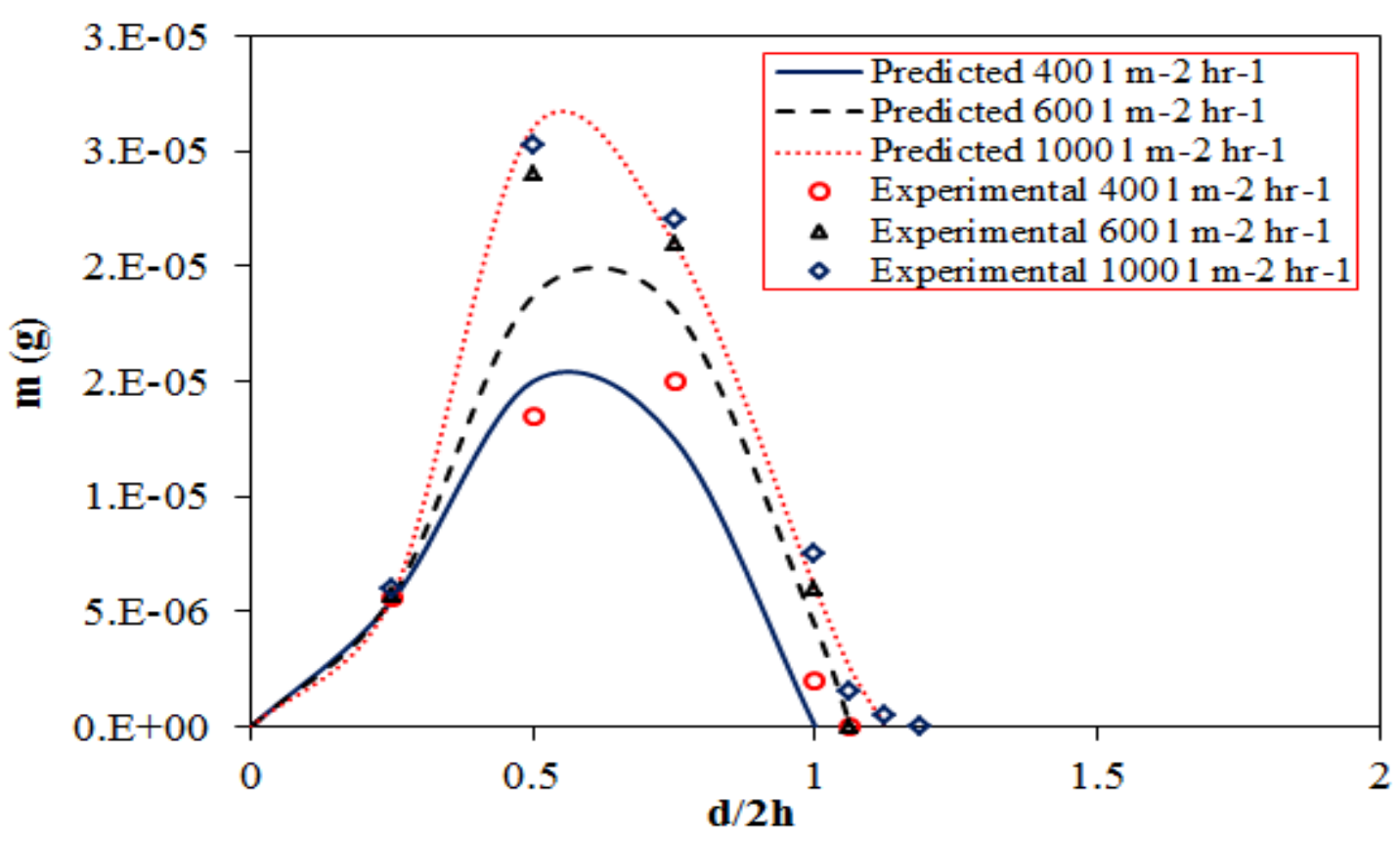

Figure 2 (c) Predicted and experimental size distributions by mass of crude oil (30 $\left.{ }^{\circ} \mathrm{API}\right)$ drops in terms of mass of oil per $2 \mathrm{ml}$ of feed measured by the Coulter Multisizer, provided by North Sea operating companies without shear rate, reducing $400 \mathrm{ppm}$ in the feed into 21,24 and $26 \mathrm{ppm}$ in the permeate at 400, 600 and $1000 \mathrm{l} \mathrm{m}^{-2} \mathrm{hr}^{-1}$ respectively. 


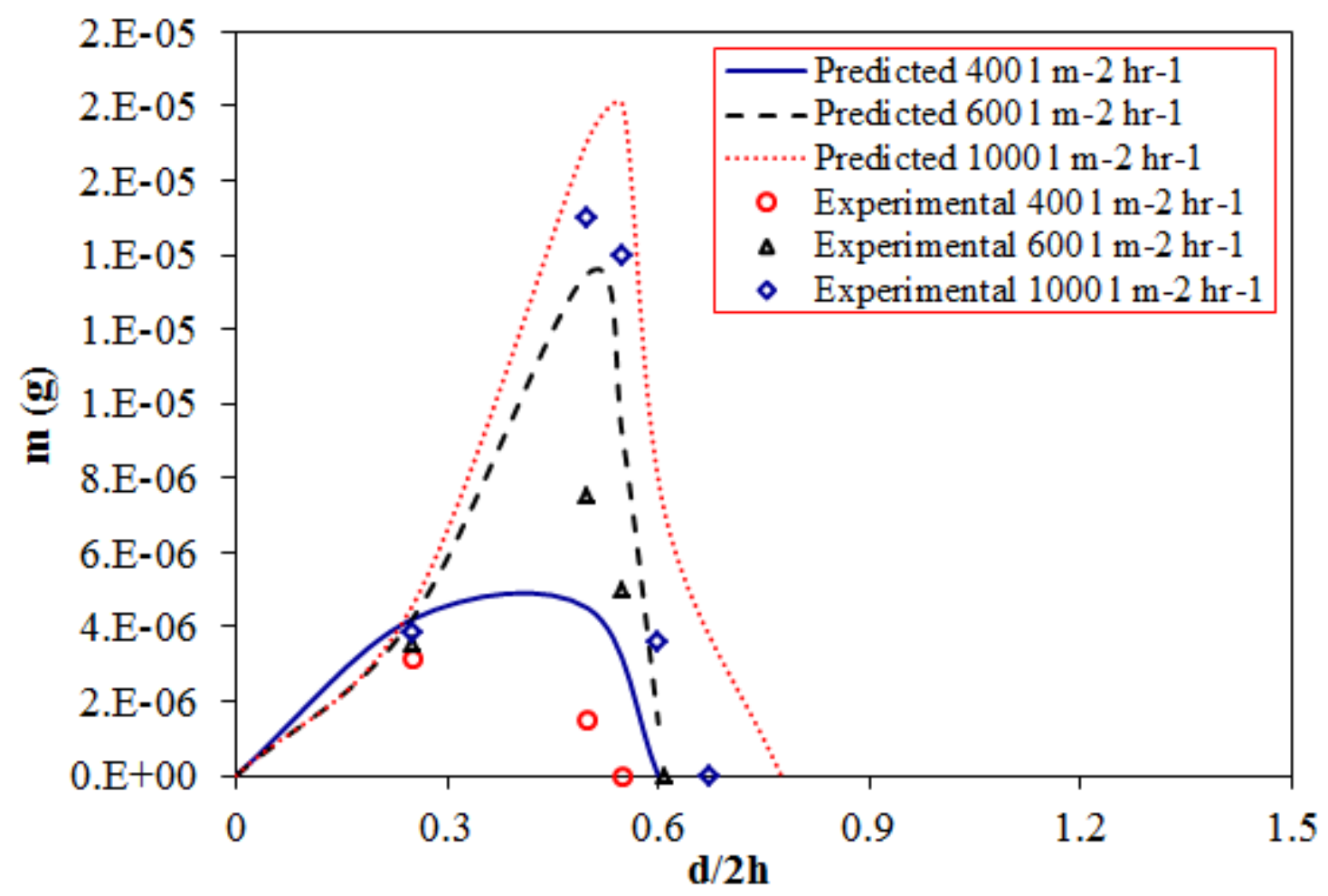

Figure 3 (a) Predicted and experimental size distributions of crude oil (30 $\left.{ }^{\circ} \mathrm{API}\right)$ drops in terms of mass of oil per $2 \mathrm{ml}$ of feed measured by the Coulter Multisizer, provided by North Sea operating companies with $10,000 \mathrm{~s}^{-1}$ shear rate, reducing $400 \mathrm{ppm}$ in the feed into 4, 6 and $8 \mathrm{ppm}$ in the permeate at 400, 600 and $1000 \mathrm{l} \mathrm{m}^{-2} \mathrm{hr}^{-1}$ respectively. 


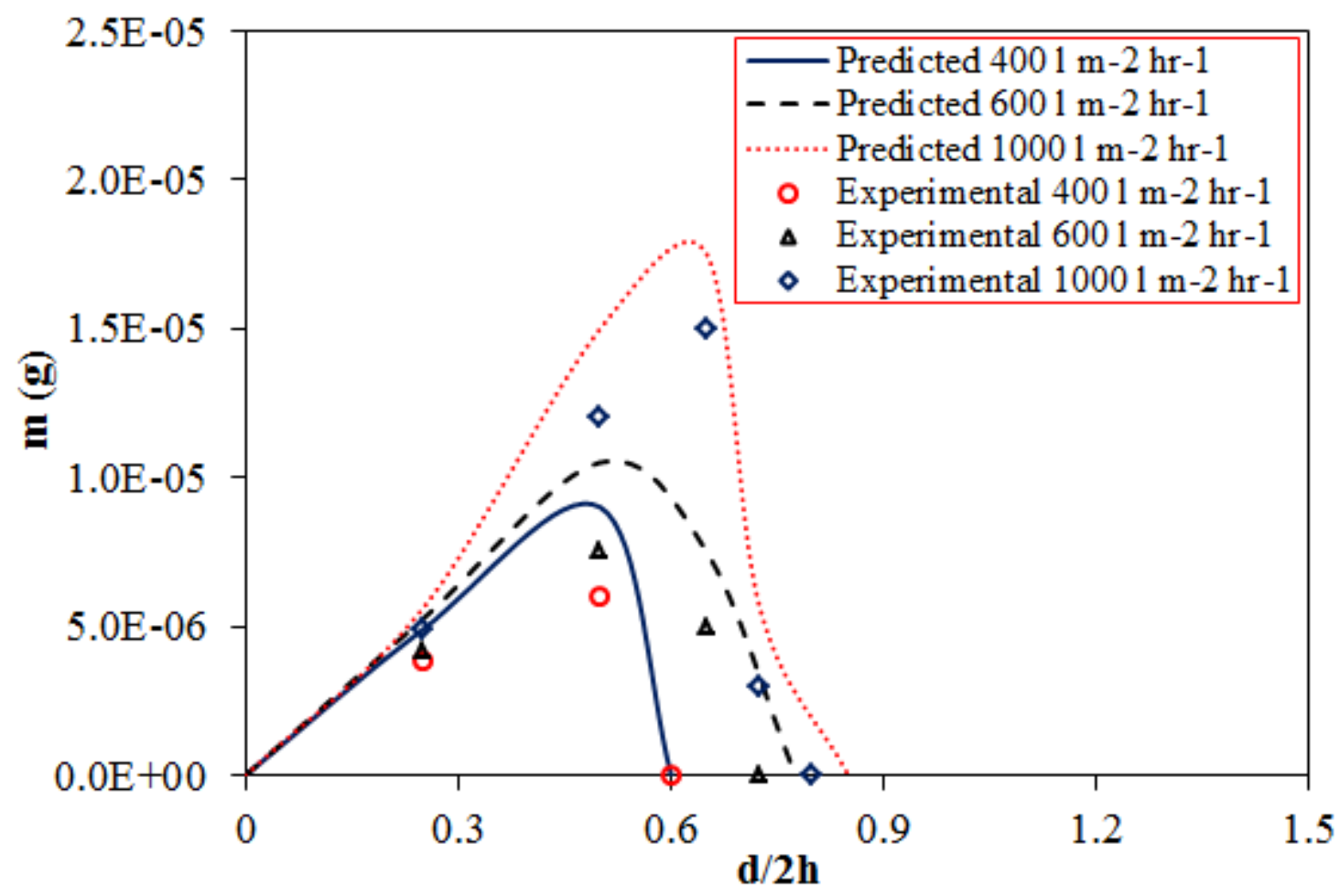

Figure 3 (b) Predicted and experimental size distributions of crude oil (30 $\left.{ }^{\circ} \mathrm{API}\right)$ drops in terms of mass of oil per $2 \mathrm{ml}$ of feed measured by the Coulter Multisizer, provided by North Sea operating companies with $8000 \mathrm{~s}^{-1}$ shear rate, and reducing $400 \mathrm{ppm}$ in the feed into 7, 9, $10 \mathrm{ppm}$ in the permeate at 400, 600 and $1000 \mathrm{l} \mathrm{m}^{-2} \mathrm{hr}^{-1}$ in the permeate respectively. 


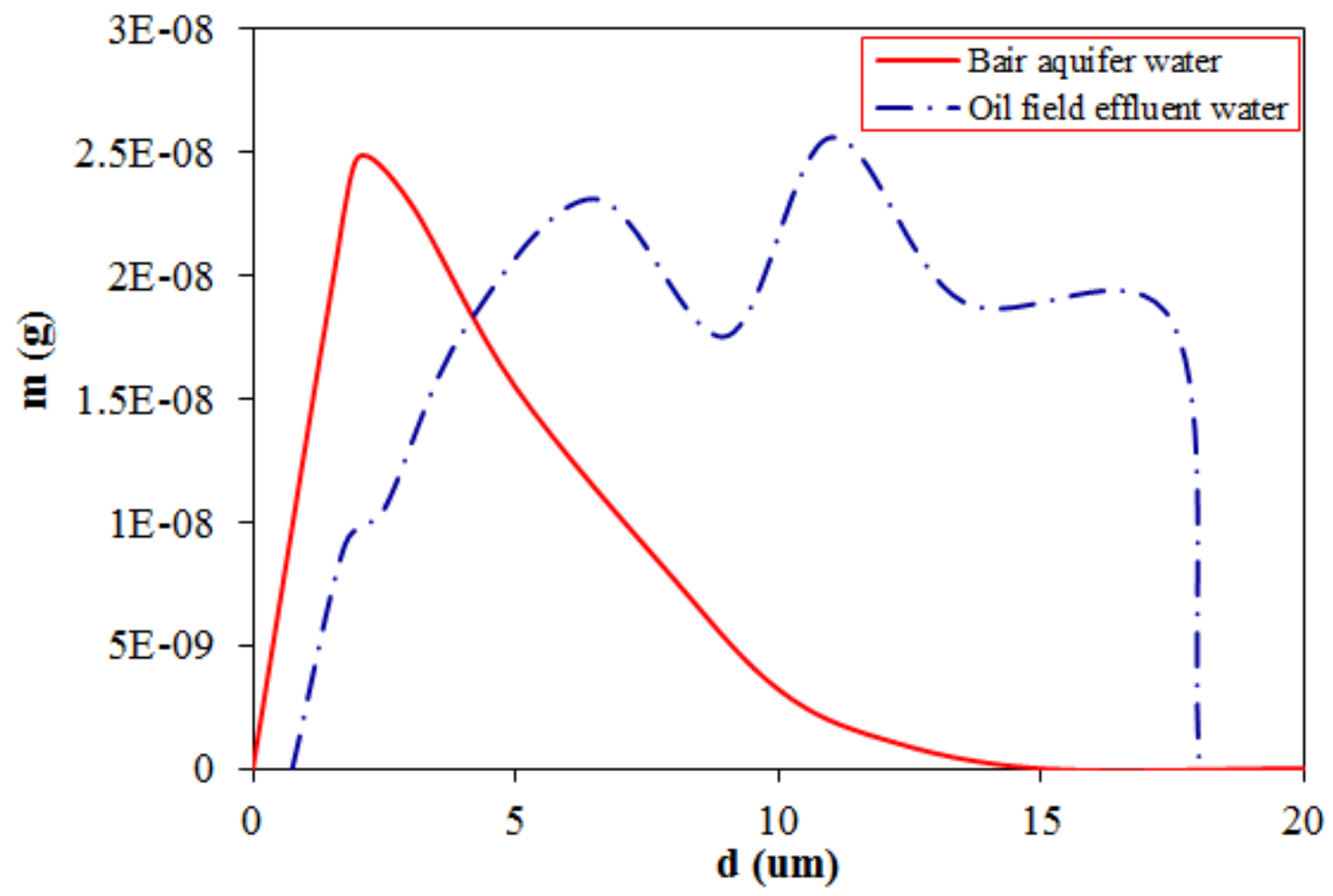

Figure 4 (a) Feed size distributions of crude oil from Kuwait crude oil operating company $\left(29^{\circ} \mathrm{API}\right)$. 


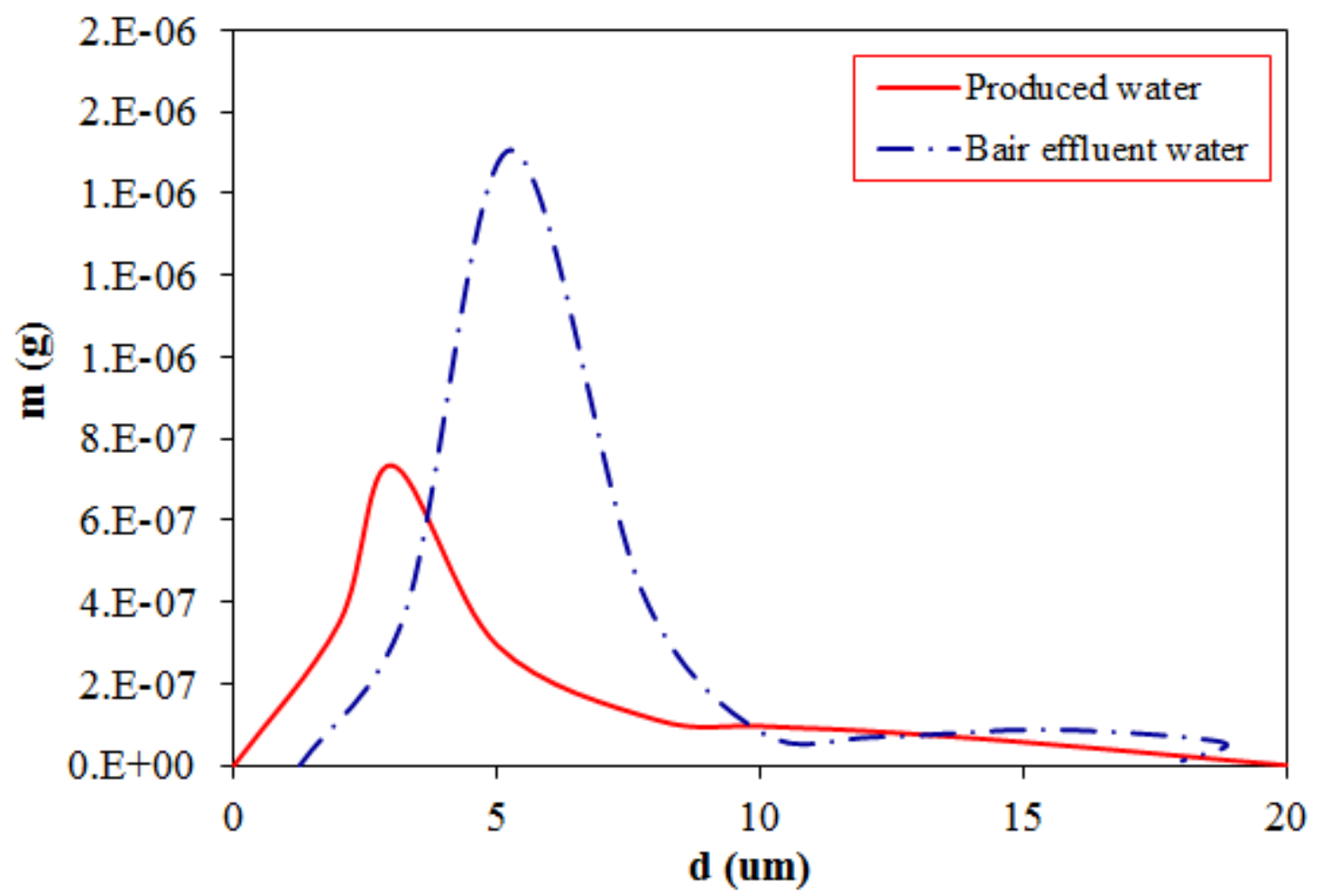

Figure 4 (b) Feed size distributions of crude oil from Kuwait crude oil operating company $\left(32^{\circ} \mathrm{API}\right)$. 


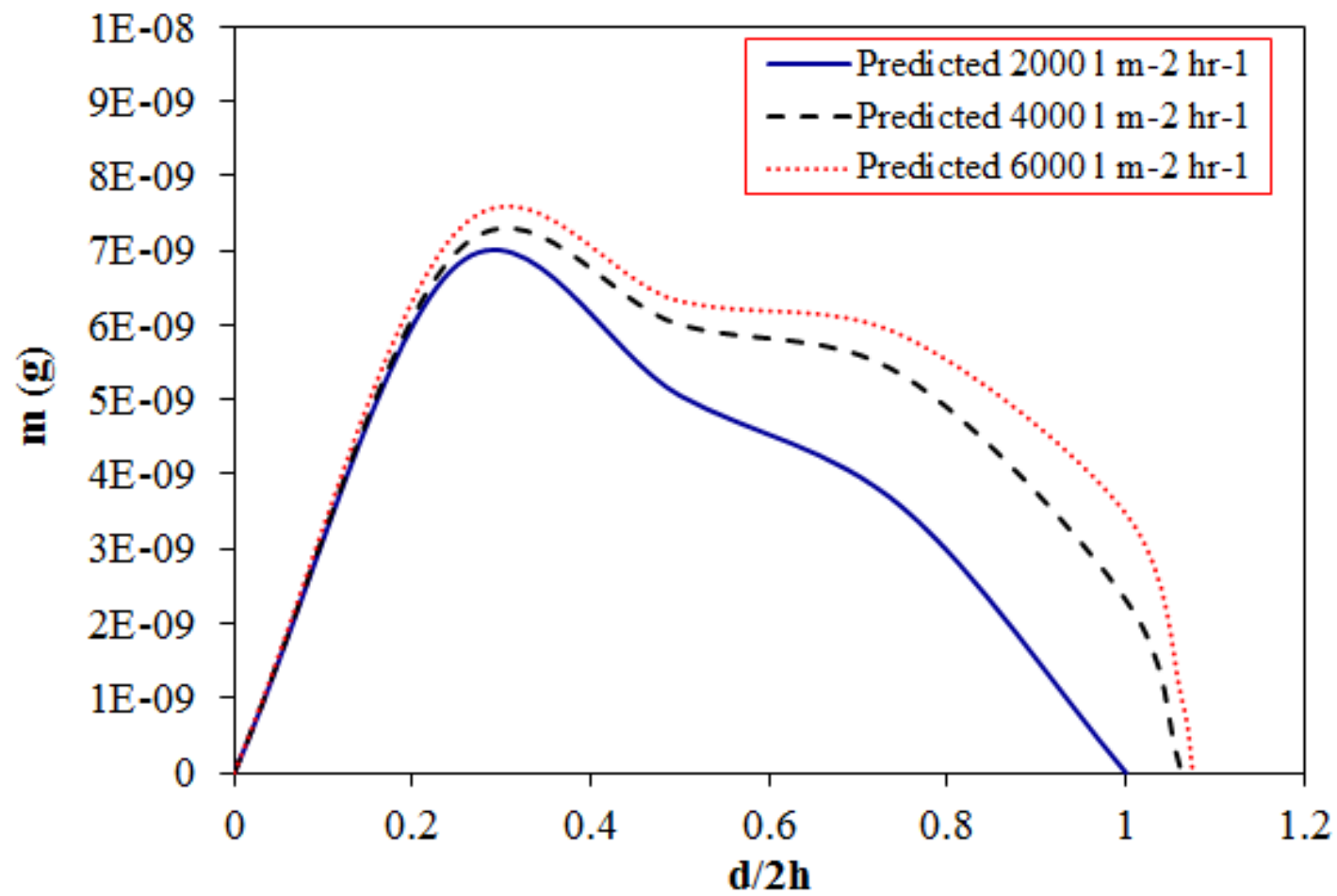

Figure 5 (a) Prediction of permeate size distributions of crude oil drops (29 $\left.{ }^{\circ} \mathrm{API}\right)$ in Oil Field Effluent Water, provided by Kuwait oil company at different flux rates without shear rate applied. 


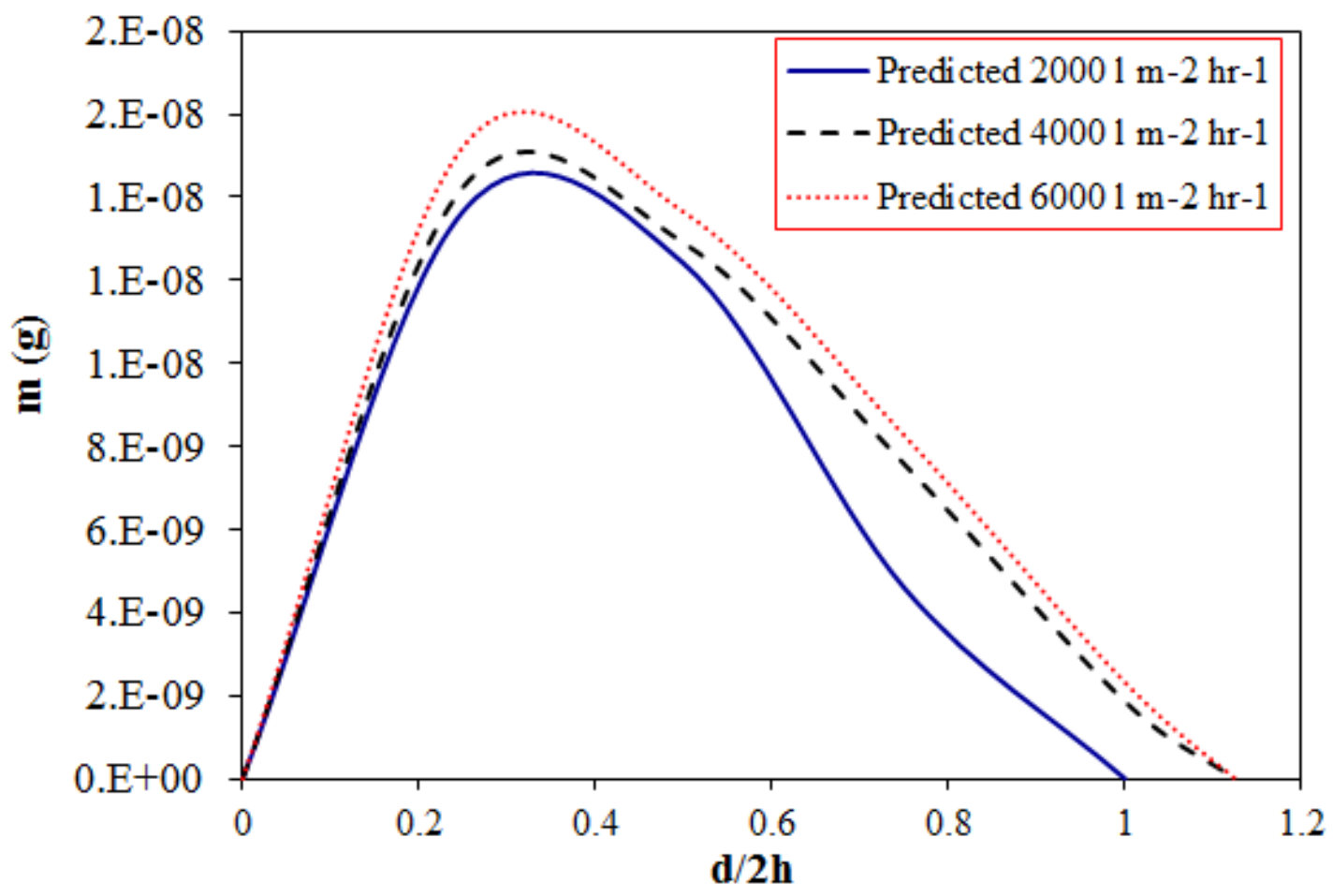

Figure 5 (b) Prediction of permeate size distributions of crude oil drops (29 $\left.{ }^{\circ} \mathrm{API}\right)$ in Bair Aquifer Water, provided by Kuwait oil company at different flux rates without shear rate applied. 


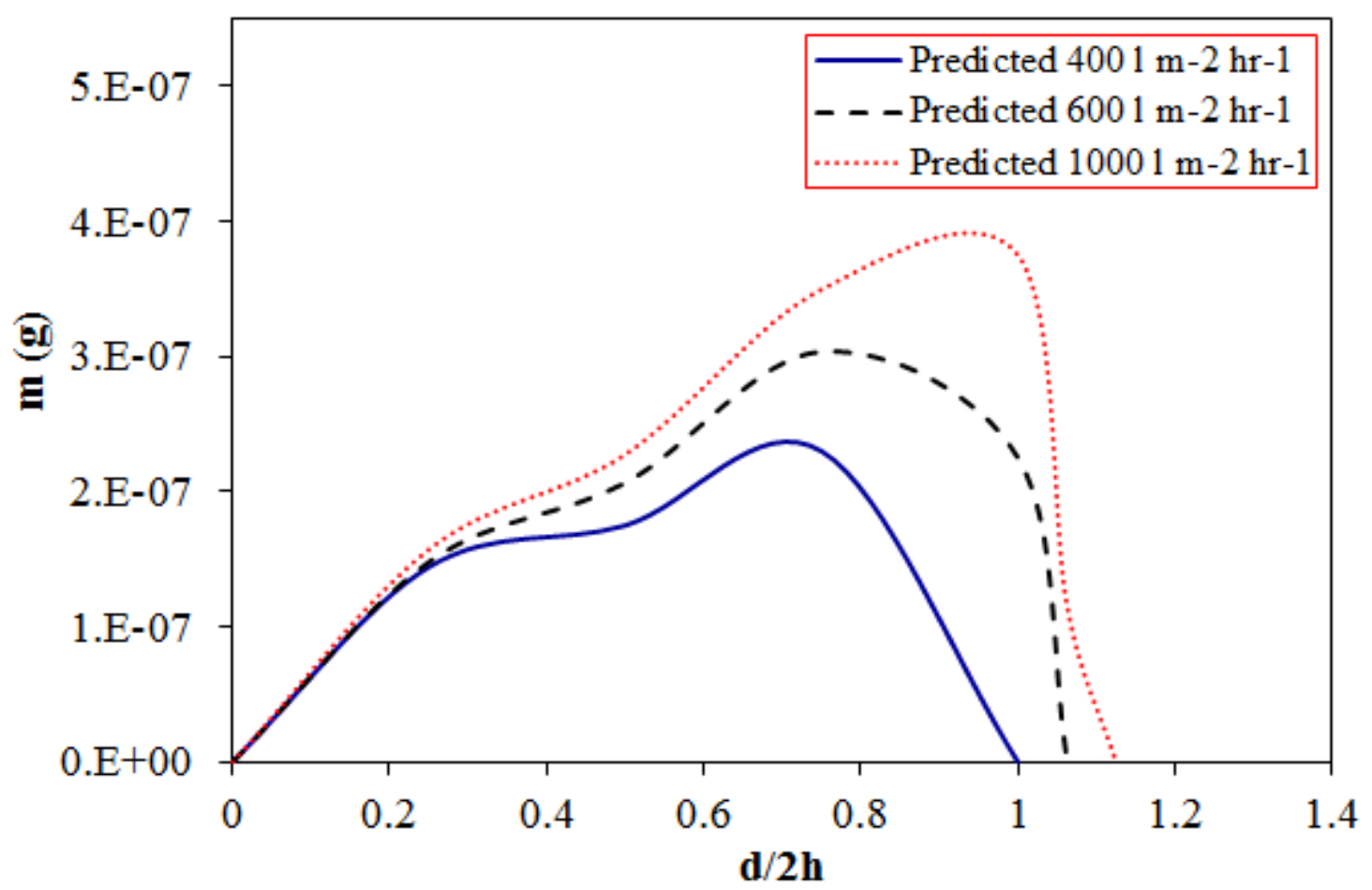

Figure 5 (c) Prediction of permeate size distributions of crude oil drops ( $\left.32^{\circ} \mathrm{API}\right)$ in Bair Effluent Water, provided by Kuwait oil company at different flux rates without shear rate applied. 


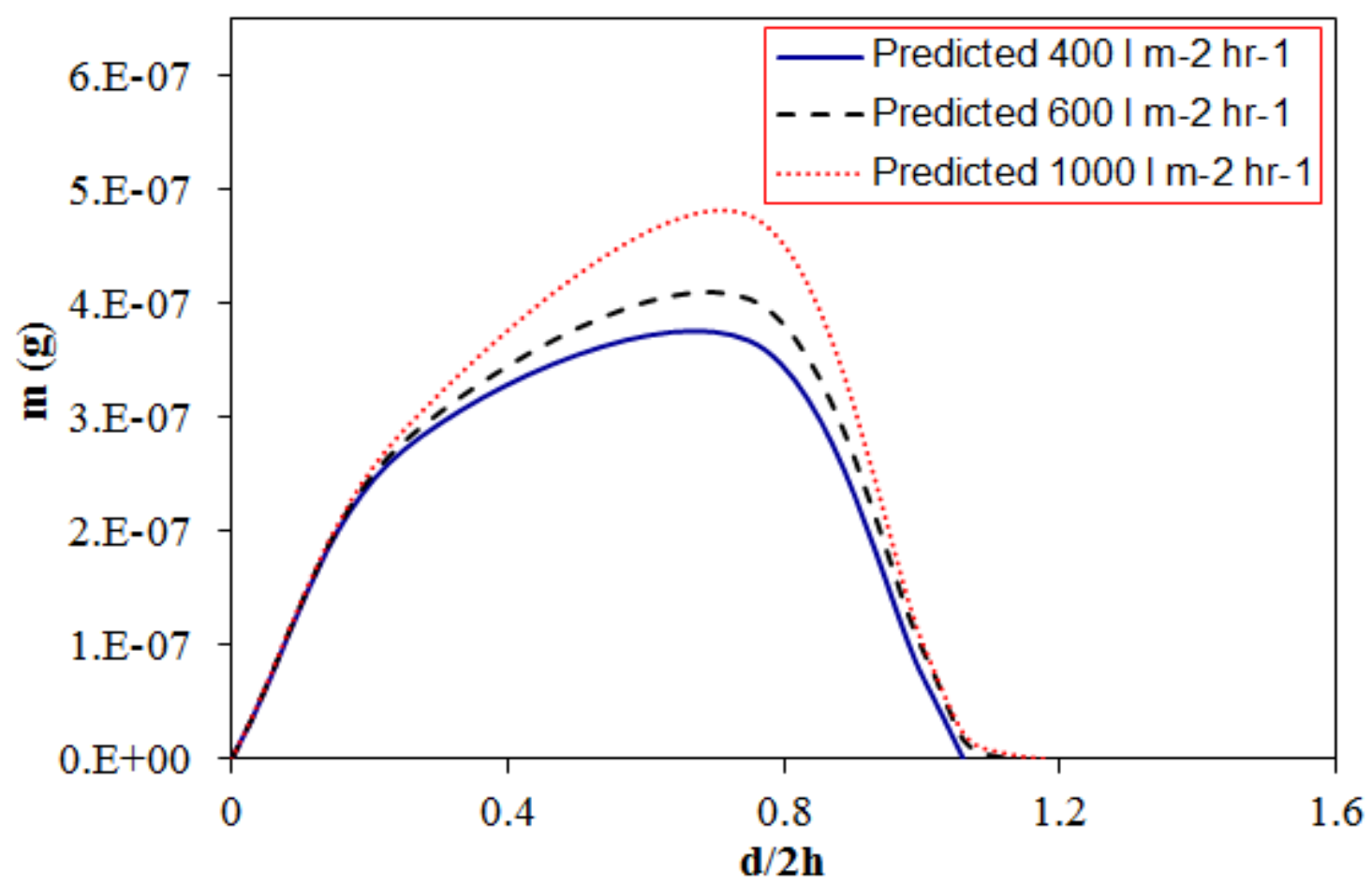

Figure 5 (d) Prediction of permeate size distributions of crude oil drops ( $\left.32^{\circ} \mathrm{API}\right)$ in Produced Water, provided by Kuwait oil company at different flux rates without shear rate applied. 